\title{
DETECÇÃO DE BACTÉRIAS PERIODONTOPATOGÊNICAS NA SALIVA DE CRIANÇAS EM FASE DE DENTADURA MISTA
}

\section{Vivien Thiemy Sakai}

Dissertação apresentada à Faculdade de Odontologia de Bauru, da Universidade de São Paulo, como parte dos requisitos para obtenção do título de Mestre em Odontologia, área de Odontopediatria.

(Edição Revisada)

BAURU

2005 


\section{DETECÇÃO DE BACTÉRIAS PERIODONTOPATOGÊNICAS NA SALIVA DE CRIANÇAS EM FASE DE DENTADURA MISTA}

\section{Vivien Thiemy Sakai}

Dissertação apresentada à Faculdade de Odontologia de Bauru, da Universidade de São Paulo, como parte dos requisitos para obtenção do título de Mestre em Odontologia, área de Odontopediatria.

(Edição Revisada)

Orientadora: Prof $^{\mathrm{a}}$. $\mathrm{Dr}^{\mathrm{a}}$. Maria Aparecida de Andrade Moreira Machado

Co-orientador: Prof. Dr. Carlos Ferreira dos Santos

BAURU

2005 
SAKAI, V T

Sa29d Detecção de bactérias periodontopatogênicas na saliva de crianças em fase de dentadura mista - Vivien Thiemy Sakai - Bauru, 2005.

91p; il.; $30 \mathrm{~cm}$

Dissertação (Mestrado) - Faculdade de Odontologia de Bauru. USP.

Orientador (a): Prof $^{\mathrm{a}}$. Dr ${ }^{\mathrm{a}}$. Maria Ap. de Andrade Moreira Machado

Autorizo, exclusivamente para fins acadêmicos e científicos, a reprodução total ou parcial desta dissertação/tese, por processos fotocopiadores elou meios eletrônicos.

Assinatura do autor:

Data: I I I

Comitê de Ética da FOB: $\quad$ Projeto de pesquisa aprovado em 25 de junho de 2003

$N^{0}$ de Protocolo: $19 / 2003$ 


\section{Universidade de São Paulo \\ Faculdade de Odontologia de Bauru}

Al. Dr. Octávio Pinheiro Brisolla, 9-75 - Bauru-SP - CEP 17012-901 - C.P. 73

PABX (0XX14)235-8000 - FAX (0XX14)223-4679

Pos-Graduafá

e-mail: posgrad@fob.usp.br-Fone: (0XX14)235-8223

\section{FOLHA DE APROVAÇÃO}

Dissertação apresentada e defendida por

VIVIEN THIEMY SAKAI

e aprovada pela Comissão Julgadora

em 10 de março de 2005.

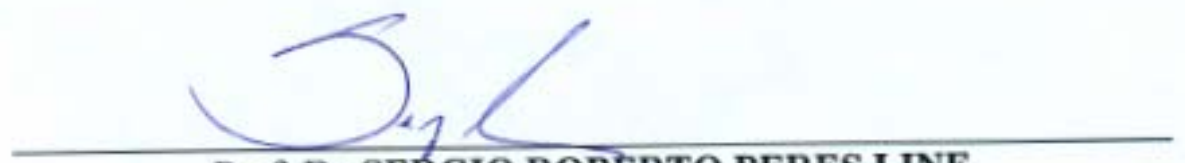

Prof. Dr. SERGIO ROBERTO PERES LINE

Faculdade de Odontologia de Piracicaba - UNICAMP

\section{Gauk my do hil}

Prof. ${ }^{2}$ Dr. "SALETE MOURA BONIFÁCIO DA SILVA

Faculdade de Odontologia de Bauru - USP

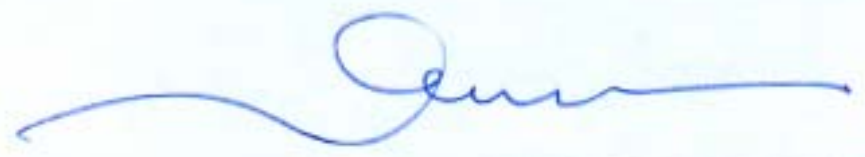

Prof. ${ }^{2}$ Dr ${ }^{2}$ MARIA APARECIDA DE ANDRADE MOREIRA MACHADO

Presidente da Banca

Faculdade de Odontologia de Bauru - USP

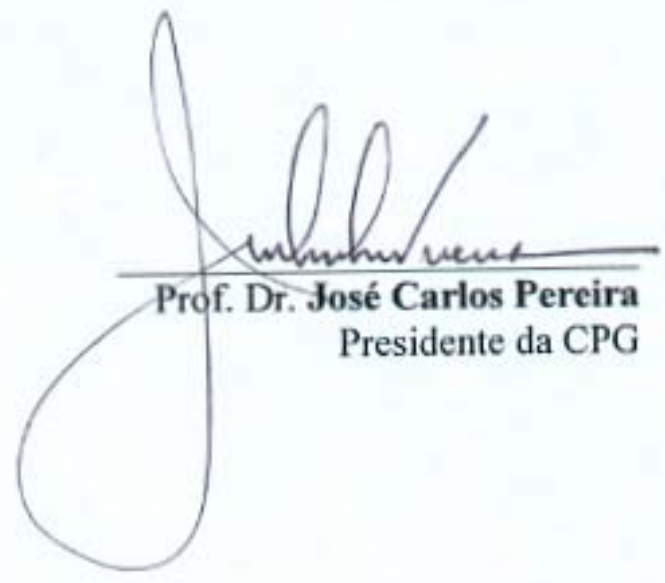


13 de fevereiro de 1981

Piracicaba - SP

Filiação

$1999-2002$

$2000-2002$

$2003-2005$

Associações
Nascimento

Emilio Sakai

Sônia Maria Buzetto Sakai

Curso de Graduação em Odontologia

- Faculdade de Odontologia de

Bauru da Universidade de São Paulo

- USP

Programa Especial de Treinamento PET, coordenado pelo Prof. Dr. Eduardo Batista Franco, com bolsa de estudo da CESU/USP

Curso de Pós-graduação em Odontologia, área de Odontopediatria, nível Mestrado Faculdade de Odontologia de Bauru da Universidade de São Paulo USP, com bolsa CNPq

- APCD - Associação Paulista de Cirurgiões-Dentistas

- CRO - SP - Conselho Regional de Odontologia

- SBPqO - Sociedade Brasileira de Pesquisa Odontológica 


\section{DEDICATÓRIA}

Aos meus pais, Sônia e Emilio, por me apoiarem nas minhas decisões e me ensinarem os verdadeiros valores da vida, sendo exemplos de dignidade, honestidade e perseverança.

Aos meus irmãos, Gisele e Rafael, que acompanham cada passo da minha vida, compartilham os meus sentimentos e vibram com cada conquista. Vocês são motivos de imenso orgulho para mim!

À minha querida cunhada Graciela, que, com sua dedicação ao trabalho e amor com que cuida de seus pacientes, serve-me de exemplo profissional e me estimula na busca de meus objetivos.

Ao meu namorado, Ricardo, pelo incansável incentivo e imensurável paciência, confortando-me nas horas tristes e vibrando com minhas vitórias. O meu maior desafio foi abdicar de nossa convivência diária, quando cada minuto de ausência parecia uma eternidade. Sem o seu amor nada valeria à pena!

A vocês, ofereço meu amor e meu carinho, que, muitas vezes, não se fazem sonoros, mas estão sempre presentes em meu coração e em meus sentimentos, e dedico este trabalho! 
“Completou-se uma jornada.

Chegar é cair na inércia de um ponto final.

Na euforia da chegada, porém,

Há um convite irrecusável

Para uma nova partida.”

Helena Kolody 


\section{AGRADECIMENTOS}

A realização deste trabalho foi fruto de muito esforço e de uma gratificante caminhada que se concretiza em mais um degrau vencido, o qual não teria sido possível sem a assistência de um grupo de pessoas talentosas, generosas e profissionais. Assim, agradeço imensamente:

- À minha querida orientadora Prof ${ }^{\mathrm{a}}$ Dr$^{\mathrm{a}}$ Maria Aparecida de Andrade Moreira Machado, que me deu a oportunidade de abraçar um projeto inovador. Ofereço minha gratidão, admiração e respeito por tantos exemplos que me proporcionou durante a nossa convivência. Sua orientação não se resume a este trabalho, mas ecoará por toda a minha vida.

- Ao meu co-orientador, incentivador e amigo Prof. Dr. Carlos Ferreira dos Santos, que generosamente sempre me apoiou, proporcionando-me as condições de trabalho e oferecendo valiosas opiniões profissionais. Simon Bolívar já dizia que "o educador deve ser não um sábio, mas sim um homem diferenciado por sua educação, pela força de seus costumes, pela naturalidade de seus modos, jovial, dócil, acessível, franco, enfim, em quem se encontre muito que imitar e pouco que corrigir". E é 
exatamente assim que eu o vejo: exemplo de verdadeiro educador!

- À Faculdade de Odontologia de Bauru - USP, na pessoa da senhora diretora, Prof $^{\mathrm{a}}$. Dr ${ }^{\mathrm{a}}$. Maria Fidela de Lima Navarro, e do senhor coordenador de pós-graduação, Prof. Dr. José Carlos Pereira.

- À coordenadora do curso de mestrado em Odontopediatria, Prof ${ }^{\mathbf{a}}$ Drª Salete Moura Bonifácio da Silva, pelo profissionalismo e dedicação com que conduz os alunos, ajudando na minha formação clínica, científica e didática.

- Aos demais professores da Odontopediatria, Dr. Rui César Camargo Abdo e Dr. José Eduardo de Oliveira Lima, pela transmissão de conhecimentos e ensinamentos durante os cursos de graduação e pós-graduação.

- Ao Departamento de Ciências Biológicas, Disciplinas de Farmacologia e Fisiologia, por ceder seus equipamentos e dependências para a realização deste trabalho. Particularmente à secretária Vera, ao mirim Maurici e aos professores Dr. Alceu e Dr. Flávio, pessoas com as quais convivi quase que diariamente e que tornaram o ambiente de trabalho sempre muito agradável. 
- Ao Thiago José Dionísio, técnico do laboratório das Disciplinas de Fisiologia e Farmacologia, que participou ativamente de todas as etapas deste trabalho, em especial da fase laboratorial. Apesar de tão jovem, é um grande exemplo de profissional, extremamente dedicado, inteligente e prestativo. Sem sua ajuda, disponibilidade e valiosas opiniões, todo o meu trabalho teria sido muito mais difícil e demorado.

- Ao Laboratório de Bioquímica, por gentilmente permitir a utilização de alguns equipamentos, em especial da máquina de gelo.

- À Dr ${ }^{\mathbf{a}}$ Elza, profissional do setor de Imunogenética do Hospital de Reabilitação de Anomalias Craniofaciais - USP (Centrinho), pela colaboração neste trabalho, permitindo gentilmente a utilização de equipamentos e material daquele setor.

- Ao Prof. Dr. José Roberto Pereira Lauris, pela disponibilidade e atenção dispensada à execução da análise estatística deste trabalho.

- Ao Prof. Dr. Ricardo Marins de Carvalho, por permitir a utilização dos equipamentos do Centro Integrado de Pesquisa (CIP) e, posteriormente, por autorizar que estes fossem levados ao 
laboratório das Disciplinas de Farmacologia e Fisiologia, facilitando todo o nosso trabalho.

- Ao Prof. Dr. Arsênio Sales Peres, por confiar na minha capacidade intelectual e didática, convidando-me para dar uma aula em seu curso. Com certeza, este foi um momento muito marcante e prazeroso, dando-me a convicção de estar no caminho certo.

- Ao Prof. Dr. Eduardo Batista Franco, tutor do Programa Especial de Treinamento (PET) durante os três anos em que fui bolsista, foi um dos responsáveis pelo início da minha vida acadêmica e científica. Agradeço pelo exemplo de grande mestre, pelo rigor na orientação científica e por estimular meu crescimento profissional e humano.

- Ao meu grande amigo, Juliano, companheiro do mestrado e confidente, por poder compartilhar com você tantos momentos felizes e tantas aflições. Obrigada por construirmos uma amizade calcada na busca comum de nossos objetivos, de forma calorosa e saudável.

- À amiga Ana Carolina M., que me ajudou na parte clínica deste trabalho e é um grande exemplo de força de vontade e determinação. 
- Às minhas queridas parceiras de clínica, Ana Carolina F. e Ana Beatriz (Tiza), que, diante de minhas limitações e pouca experiência, sempre me ajudaram e tornaram nossa convivência bastante agradável. Obrigada por me ajudarem a trabalhar em grupo e por enriquecerem minha vida.

- Às demais colegas do curso de mestrado Sandra, Helena e Érica, pelos momentos de alegria e descontração que vocês me proporcionaram. Também aos colegas do doutorado, Thaís, Heitor, Marcelo, Adriano, Marina, Érika, Gladis e Thiago (Senil) pela convivência e troca de experiências.

- Às funcionárias da Odontopediatria, Fátima, D. Lia, Estela e Lílian, que, com o carinho e a solicitude com que me receberam, tornaram a convivência alegre e produtiva.

- A todas as crianças do meu relacionamento profissional e particular, que são a motivação permanente para a minha dedicação ao campo da Odontopediatria.

- Ao Conselho Nacional de Desenvolvimento Científico e Tecnológico (CNPq), pelo apoio financeiro concedido durante a realização deste trabalho (processo $n^{0} 132701 / 2003-0$ ). 
As palavras para expressar minha gratidão a todos vocês seriam muitas, porém deixo registrado apenas o meu sincero e singelo MUITO OBRIGADA! 


\section{SUMÁRIO}

RESUMO

1 INTRODUÇÃO

2 REVISÃO DE LITERATURA....................................................... 8

3 PROPOSIÇÃO

4 MATERIAL E MÉTODOS ............................................................ 26

4.1 Seleção de pacientes............................................................. 27

4.2 Anamnese

4.3 Coleta de saliva

4.4 Avaliação do índice gengival (IG) ………………………........ 29

4.5 Extração de DNA das amostras de saliva .................................. $\quad 30$

4.6 Reação em cadeia da polimerase (PCR) ………...................... 32

4.7 Eletroforese horizontal.......................................................

4.8 Análise estatística................................................................. 35

5 RESULTADOS

5.1 Primeira avaliação: novembro de 2003 ..................................... 37

5.2 Segunda avaliação: novembro de 2004..................................... 41

5.3 Comparação entre os resultados obtidos em novembro de 2003 e novembro de 2004

6 DISCUSSÃO

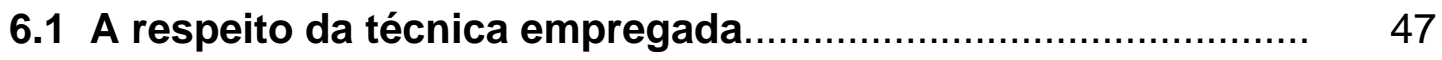

6.2 A respeito dos resultados obtidos............................................ 53

6.2.1 Detecção de Porphyromonas gingivalis.................................. 57 
6.2.2 Detecção de Treponema denticola.

6.2.3 Detecção de Actinobacillus actinomycetemcomitans............ 61

6.2.4 Detecção de Prevotella nigrescens.................................... 63

6.2.5 Avaliação da combinação de espécies bacterianas................ 64

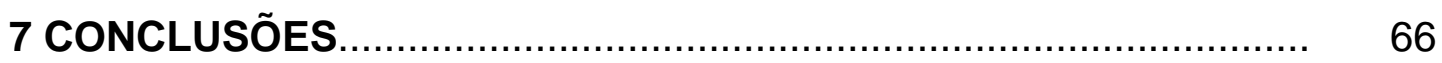

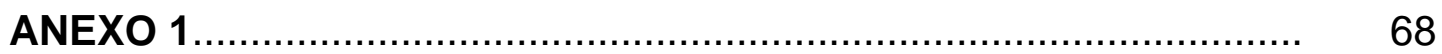

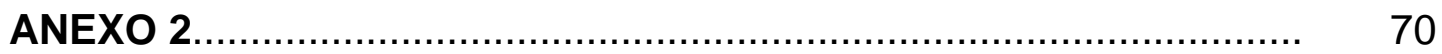

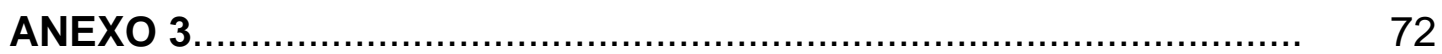

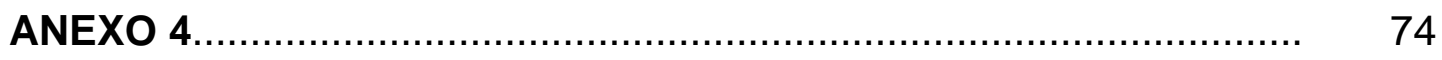

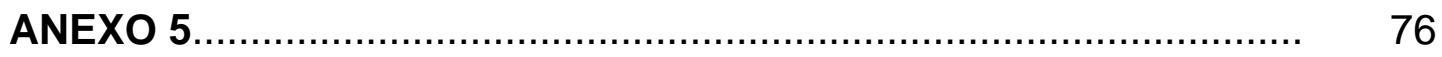

REFERÊNCIAS BIBLIOGRÁFICAS......................................... 78

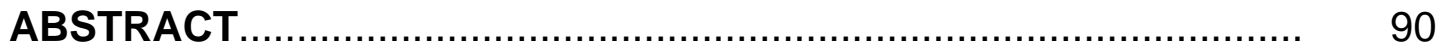




\section{RESUMO}

Avaliar a prevalência de 4 bactérias periodontopatogênicas potenciais (Actinobacillus actinomycetemcomitans, Porphyromonas gingivalis, Prevotella nigrescens e Treponema denticola), por meio da técnica da reação em cadeia da polimerase $(\mathrm{PCR})$, na saliva de crianças com dentadura mista e correlacionar estes achados com um parâmetro clínico de saúde gengival, o índice gengival (IG). Além disso, a fim de se verificar a estabilidade de colonização destas bactérias, todas as crianças foram reavaliadas após um ano. Sessenta e duas $(96,9 \%)$ e $50(83,3 \%)$ crianças apresentaram baixa inflamação gengival, enquanto que $2(3,1 \%)$ e 10 $(16,7 \%)$ tiveram escores moderados nas avaliação realizadas em 2003 e 2004, respectivamente. A maioria dos pacientes $(81,3 \%$ na primeira avaliação e 73,3\% na segunda) apresentou níveis detectáveis de pelo menos um dos microrganismos estudados. A prevalência encontrada nesta população foi de 4,7\% e 1,7\% para $A$. actinomycetemcomitans, 6,3\% e 8,3\% para $P$. gingivalis, $23,4 \%$ e $48,3 \%$ para $P$. nigrescens e $71,9 \%$ e $50 \%$ para $T$. denticola nos anos de 2003 e 2004, respectivamente. Não se verificou relação estatística significativa entre o IG e a presença destas bactérias e da combinação das diferentes espécies bacterianas nos dois momentos avaliados. Apesar dos baixos valores do IG, uma alta porcentagem dos pacientes abrigava pelo menos um periodontopatógeno potencial na saliva em idade precoce em ambos os períodos avaliados. Portanto, devem-se adotar medidas preventivas para estes pacientes a fim de evitar o estabelecimento e desenvolvimento de doença periodontal no futuro. 
1 Introdução 


\section{INTRODUÇÃO}

Doença periodontal corresponde a um grupo de condições que afetam a gengiva, o ligamento periodontal, o cemento, o osso alveolar e as estruturas teciduais de suporte do dente ${ }^{35}$. É causada pela infecção destes tecidos decorrente do acúmulo de placa bacteriana, podendo resultar na migração apical do tecido epitelial e na perda progressiva de inserção conjuntiva e osso alveolar ${ }^{42}$.

A forma predominante de doença periodontal em crianças e adolescentes é a gengivite, uma reação inflamatória não específica confinada à margem gengival, sem destruição de tecido duro ${ }^{2,35}$. Essa reação inflamatória no tecido, iniciada pelo acúmulo de placa, começa precocemente durante a infância e reflete o desafio bacteriano no hospedeiro. Na maioria das crianças, o processo de inflamação gengival permanece superficial. Em alguns casos, entretanto, o equilíbrio entre o desafio microbiano e a resposta do hospedeiro é quebrado, levando a um processo inflamatório que também afeta o osso alveolar, resultando na perda de inserção do dente ${ }^{35}$.

A partir daí, tem-se início a periodontite, a qual afeta significativamente a saúde bucal de muitos indivíduos, podendo levar à perda dentária, bem como compromete potencialmente a sua saúde sistêmica e a sua qualidade de vida ${ }^{27,48}$. Dependendo dos microrganismos infectantes e da resposta resultante do hospedeiro, a periodontite pode ser classicamente dividida em quatro entidades distintas: periodontite como uma 
manifestação de doenças sistêmicas, periodontite agressiva (juvenil), periodontite crônica e doença periodontal necrosante $e^{2,3,23}$.

Bactérias iniciam uma cascata de processos celulares e moleculares através de três maneiras diferentes: 1) enzimas proteolíticas bacterianas degradam estruturas do estroma sem a intervenção de células do hospedeiro; 2) produtos bacterianos (toxinas, lipopolissacarídeos, enzimas) podem diretamente disparar, nas células residentes (fibroblastos, células endoteliais e, possivelmente, osteoblastos) e nas células migratórias (polimorfonucleares, linfócitos e macrófagos), a expressão de enzimas degradantes, mediadores inflamatórios e fatores de crescimento; 3) e, finalmente, estas células do hospedeiro também podem causar respostas imunes $^{37}$.

Na cavidade bucal, há um grande número de microrganismos, com diferentes potenciais de virulência, que constituem sua microbiota normal $^{3,27,42}$. A aquisição e a transmissão de microrganismos causadores de doenças periodontais dependem da maneira como os indivíduos interagiram com o meio ambiente desde o nascimento, o que inclui hábitos de higiene bucal, dieta e nutrição, bem como do contato com indivíduos que já apresentam a doença. Se a infância é um período crítico para a aquisição de certas bactérias, parece provável que muitas crianças adquirem os microrganismos dos pais ou de outras pessoas com as quais têm contato mais próximo. Dados evidenciam que se uma criança abriga um dos patógenos periodontais, pelo menos um dos pais também é positivo para 
aquela bactéria ${ }^{17}$. Entretanto, a incidência da transferência bacteriana para as crianças é variável.

Algumas espécies bacterianas, caracterizadas como microrganismos gram-negativos anaeróbios ou facultativos, podem ter um papel importante na patogênese das formas mais agressivas de periodontite ${ }^{3}$. Apesar de a identidade destes organismos permanecer controversa e ser assunto de intensa pesquisa, há ampla concordância de que entre os periodontopatógenos estão Porphyromonas gingivalis, Prevotella intermedia, Prevotella nigrescens, Actinobacillus actinomycetemcomitans, Fusobacterium nucleatum, Eikenella corrodens, Treponema denticola e um número de espiroquetas ainda não identificadas ${ }^{15,21,27,32,41,42,53,55,60}$. Estas bactérias produzem toxinas que irritam os tecidos periodontais e causam diversas respostas imunes no hospedeiro, induzindo um desarranjo periodontal $^{27,37,53}$.

O número de microrganismos num sítio específico (mucosa, língua, placa subgengival, placa supragengival, saliva, etc.) pode ser baixo, porém sua presença pode identificar o risco de o paciente vir a desenvolver a doença periodontal ${ }^{59}$. Além disso, combinações de diferentes espécies bacterianas, ao invés de espécies únicas, podem produzir um potencial patogênico suficiente para causar a progressão de gengivite para periodontite ${ }^{54}$

A detecção de bactérias periodontopatogênicas é geralmente realizada por métodos de cultura, os quais nem sempre apresentam sensibilidade suficiente e requerem habilidades especiais, principalmente 
quando do isolamento de bactérias anaeróbias. Vários outros métodos para a detecção de bactérias periodontopatogênicas vêm sendo utilizados, tais como testes enzimáticos e imunológicos e sondas de DNA específicas para determinadas espécies. Nos últimos anos, a reação em cadeia da polimerase (PCR) tem sido empregada para a detecção destas bactérias $^{9,16,21,27,32,34,38,39,46,53,54,58,60}$. A PCR é uma técnica rápida, relativamente simples e capaz de detectar baixos números de espécies bacterianas, com um limite de detecção de algumas a $10^{2}$ células $^{30,51,58}$. Desta forma, a PCR é considerada uma técnica adequada para a detecção de microrganismos periodontopatogênicos, especialmente em situações em que há um número limitado de patógenos presentes, como na placa subgengival ${ }^{10,32,34,53}$ e na saliva ${ }^{30,44-46,53,55}$ de crianças.

No estudo da comunidade bacteriana bucal, a saliva parece ser a amostra mais adequada, visto que ela contém uma variedade de bactérias de diferentes sítios bucais ${ }^{44,45,55,56}$. Contudo, SAKAMOTO et al. ${ }^{44}$, em 2000, sugeriram que os microrganismos subgengivais, especialmente bactérias periodontopatogênicas, existem apenas em baixo número na saliva, e que, se patógenos periodontais estiverem focados no estudo da microbiota bacteriana, o uso da placa subgengival seria mais eficiente e informativo do que o uso da saliva. Entretanto, outros trabalhos apontaram que bactérias periodontopatogênicas foram detectadas com maior freqüência em amostras de saliva em comparação com amostras de placa subgengival ${ }^{43,45,56}$, demonstrando ser um bom indicador de colonização bucal. Além disso, a utilização de saliva possibilita uma padronização quantitativa da amostra ${ }^{57}$, 
isto é, permite coletar um mesmo volume de amostra de diferentes pacientes. Ela representa também uma amostra de fácil obtenção, sem a necessidade de utilização de técnicas invasivas durante a sua coleta $^{30,44,55,57}$, o que é particularmente importante em estudos com crianças.

A investigação da colonização precoce dos tecidos periodontais por bactérias periodontopatogênicas pode representar ferramenta de particular importância para a prevenção e o tratamento da doença periodontal. Especialmente em crianças na fase de dentadura mista, é possível que esses patógenos permaneçam nas áreas circunjacentes aos dentes decíduos que sofrem esfoliação, continuando a se multiplicar no sulco gengival ao redor dos dentes permanentes ${ }^{19,39,60}$. Além disso, durante a dentadura mista, a inflamação gengival elevada, resultante de uma pobre higiene bucal, pode levar à formação de bolsas falsas, podendo contribuir para a colonização de patógenos periodontais e atuar como um reservatório de bactérias. Estudo recente revelou que a higiene bucal neste período de transição da dentição decídua para a permanente é precária, podendo explicar a maior prevalência de detecção de algumas bactérias periodontopatogênicas ${ }^{55}$. Ademais, em pacientes em fase de dentadura mista, certos tipos de bactérias foram associados ao sangramento à sondagem em dentes decíduos e permanentes ${ }^{19}$.

Desta forma, para avaliar a epidemiologia de patógenos periodontais bem como o diagnóstico e o tratamento de doenças periodontais, muitas espécies de importância etiológica precisam ser detectadas. Existem, entretanto, poucos estudos que fazem um acompanhamento longitudinal da 
colonização microbiana e da saúde gengival durante a infância em populações saudáveis ${ }^{36}$, sendo difícil distinguir uma colonização permanente (ou aquisição freqüente) de uma detecção transitória dos microrganismos. Além disso, a relação entre parâmetros clínicos, como o índice gengival, e a distribuição de vários periodontopatógenos ainda não é bem entendida ${ }^{54}$. 
2 Revisão de Literatura

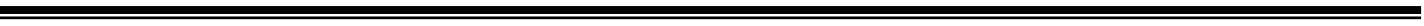




\section{REVISÃO DE LITERATURA}

Diversos são os estudos que procuram identificar espécies de bactérias periodotopatogênicas em indivíduos saudáveis e/ou periodontalmente comprometidos. Para isto, várias técnicas laboratoriais têm sido empregadas com sucesso, dentre elas a PCR, as técnicas imunológicas, os meios de cultura, entre outras. Ademais, muitos autores procuram correlacionar os achados microbiológicos com parâmetros clínicos de saúde periodontal em indivíduos de diversas faixas etárias (crianças, adolescentes ou adultos).

KAMMA et al. ${ }^{19}$, em 2000, coletaram amostras de placa subgengival e submeteram-nas a um meio de cultura bacteriana com o intuito de investigar a composição da microbiota subgengival de diferentes grupos de dentes (incisivos e molares permanentes e caninos e molares decíduos) em 40 crianças em fase de dentadura mista. Quarenta e quatro espécies diferentes foram isoladas tanto de dentes decíduos como de dentes permanentes. Os resultados indicaram que estas crianças abrigavam bactérias anaeróbicas gram-negativas multiformes, algumas das quais suspeitas de serem patógenos periodontais.

MORINUSHI et al. ${ }^{36}$, em 2000, avaliaram a relação entre a detecção de $P$. gingivalis e $A$. actinomycetemcomitans na placa subgengival pela técnica de "slot immunoblot", a presença de anticorpos séricos contra estes microrganismos e o nível de inflamação gengival em uma população de 40 indivíduos saudáveis entre 2 e 18 anos. $P$. gingivalis e $A$. 
actinomycetemcomitans estavam presentes em níveis detectáveis em mais de $60 \%$ e de $75 \%$ dos indivíduos, respectivamente, havendo uma diminuição da colonização com o aumento da idade. Contudo, não foi encontrada relação significativa entre títulos de anticorpos e a colonização por estas bactérias. Além disso, observou-se um aumento progressivo da inflamação gengival até os 12 anos, diminuindo a partir desta idade.

No estudo conduzido por TANAKA et al. ${ }^{54}$, em 2002, a técnica de "slot immunoblot" também foi utilizada para avaliar a associação entre alguns parâmetros clínicos (índice de placa, índice gengival e profundidade de sondagem) e a distribuição de $P$. gingivalis, $P$. intermedia, $P$. nigrescens e Prevotella melaninogenica em amostras de placa supra e subgengival de 299 pacientes com idade entre 6 e 69 anos. Os autores encontraram um índice de placa aumentado em crianças positivas para qualquer uma das quatro bactérias estudadas, bem como um aumento do índice gengival à medida que se aumentava a quantidade de $P$. intermedia e $P$. nigrescens.

WAHLFORS et al. $^{58}$, em 1995 , desenvolveram um método de PCR "multiplex" para detecção simultânea de $A$. actinomycetemcomitans e $P$. gingivalis de maneira rápida e fácil em amostras de placa subgengival de 36 adultos com doença periodontal. Os resultados obtidos utilizando-se esta técnica indicaram uma prevalência de $44 \%$ para $A$. actinomycetemcomitans e 56\% para $P$. gingivalis, enquanto que, por meio da técnica de cultura, esta prevalência foi consideravelmente menor (25\% e 42\%, respectivamente).

GAFAN et al. $^{13}$, em 2004, também utilizaram a técnica da PCR "multiplex" para detecção de $P$. gingivalis, $A$. actinomycetemcomitans e 
Tannerella forsythensis em 118 crianças com idade entre 5 e 9 anos, com e sem gengivite. Para aquelas com gengivite, os resultados foram: $P$. gingivalis, 47\%; A. actinomycetemcomitans, 59\%; e T. forsythensis, 45\%. Já para as crianças sem gengivite, encontraram-se $49 \%$ de $P$. gingivalis, $55 \%$ de $A$. actinomycetemcomitans e $65 \%$ de $T$. forsythensis.

DOUNGUDOMDACHA, RAWKINSON e DOUGLAS ${ }^{12}$, em 2000, desenvolveram um sensível método de PCR quantitativo-competitivo, utilizando primers específicos, para a identificação de $P$. gingivalis, $P$. intermedia e A. actinomycetemcomitans tanto em cepas laboratoriais quanto em amostras de placa subgengival. Este método provou ser rápido, reproduzível e extremamente sensível, e os primers empregados foram altamente específicos e capazes de diferenciar os microrganismos-alvo de diversas outras espécies bacterianas semelhantes.

A técnica da PCR convencional foi empregada em diversos estudos que envolvem a detecção de potenciais bactérias causadoras de doença periodontal. No estudo de MCCLELLAN, GRIFFEN e LEYS ${ }^{33}$, em 1996, procurou-se examinar a freqüência de $P$. gingivalis na cavidade bucal de 198 indivíduos entre 0 e 18 anos de idade. Esta bactéria foi encontrada em 37\% dos indivíduos e em freqüências semelhantes em todas as faixas etárias.

Da mesma forma, WATANABE e FROMMEL ${ }^{59}$, em 1993, detectaram a presença de $P$. gingivalis em amostras de placa subgengival de indivíduos com doença periodontal. Os resultados indicaram que cinco das 13 amostras obtidas de adultos com periodontite avançada e duas amostras de crianças também com periodontite avançada foram positivas para aquela bactéria. 
Os mesmos autores, em 1996, propuseram-se a detectar a presença de três prováveis patógenos periodontais, $A$. actinomycetemcomitans, $P$. gingivalis e $T$. denticola, na placa subgengival de indivíduos com periodontite avançada (4 a 51 anos de idade). Usando 27 ciclos de PCR, 4 amostras foram positivas para A. actinomycetemcomitans, 8 para $P$. gingivalis e 25 para T. denticola. Aumentando-se para 32 ciclos, 5, 2 e 4 amostras adicionais foram positivas para aquelas bactérias, respectivamente ${ }^{60}$.

Avaliando amostras de placa de indivíduos periodontalmente saudáveis, CONRADS et al. ${ }^{10}$, em 1996, procuraram determinar a distribuição de alguns prováveis patógenos periodontais $(P$. intermedia, $P$. nigrescens, P. gingivalis, A. actinomycetemcomitans e as três espécies bucais de Capnocytophaga) em crianças e adultos. As técnicas da PCR e de hibridização "dot-blot" foram utilizadas para detectar, diferenciar e quantificar estas bactérias diretamente da placa subgengival. Apenas $P$. nigrescens e Capnocytophaga ochracea foram encontradas, sendo que as demais espécies bacterianas não foram detectadas nestes pacientes com a utilização destes métodos.

ASHIMOTO et al. ${ }^{4}$, em 1996, realizaram PCR com os genes $16 \mathrm{~S}$ rRNA de oito espécies bacterianas (A. actinomycetemcomitans, B. forsythus, C. rectus, E. corrodens, $P$. gingivalis, $P$. intermedia, $P$. nigrescens e $T$. denticola) a fim de se determinar a prevalência de possíveis periodontopatógenos em 50 pacientes com periodontite avançada, 50 adultos com gengivite branda e 50 crianças com gengivite branda. As prevalências para as espécies A. actinomycetemcomitans, $P$. gingivalis, $P$. 
nigrescens e $T$. denticola foram de $22 \%$ ou menos em adultos e crianças com gengivite, sugerindo que estes microrganismos não são os componentes principais da placa subgengival em pacientes sem periodontite. A prevalência desses microrganismos foi significativamente maior em indivíduos com periodontite avançada, variando de $30 \%$ para $A$. actinomycetemcomitans a 50\% para as demais espécies.

OKADA, HAYASHI e NAGASAKA ${ }^{38}$, em 2000, também utilizaram a técnica da PCR com o objetivo de detectar a presença de $A$. actinomycetemcomitans e $P$. gingivalis em amostras de placa dentária coletadas da escova de dentes de 104 crianças entre 2 e 12 anos de idade. A prevalência de $A$. actinomycetemcomitans em indivíduos saudáveis foi de 4,8\%, e em indivíduos com gengivite e periodontite foi de $6,8 \%$ e $20 \%$, respectivamente. P. gingivalis foi encontrada em 4,8\% das crianças saudáveis, em $9,6 \%$ daquelas com gengivite e em $20 \%$ das com periodontite. Os resultados indicaram que estas duas bactérias raramente estão presentes na cavidade bucal de crianças.

No ano seguinte, estes autores propuseram-se a detectar a presença de outras cinco bactérias periodontopatogênicas $(P$. intermedia, $P$. nigrescens, Bacteroides forsythus, T. denticola e Campylobacter rectus) em 119 crianças, utilizando a mesma metodologia do trabalho anterior. As crianças foram divididas em três grupos: 24 com gengiva saudável, 83 com gengivite e 12 com periodontite. A prevalência encontrada para pacientes saudáveis, com gengivite e com periodontite foi de $0 \%, 6 \%$ e $25 \%$ para $P$. intermedia, $45,8 \%, 79,5 \%$ e $50 \%$ para $P$. nigrescens, $33,3 \%, 63,9 \%$ e $58,3 \%$ 
para $B$. forsythus, $0 \%, 18,1 \%$ e $16,7 \%$ para $T$. denticola, respectivamente, e 100\% em duplicata para C. rectus ${ }^{39}$.

KIMURA et al. ${ }^{21}$, em 2002, avaliaram a prevalência e a distribuição de periodontopatógenos na placa supragengival de 144 crianças, periodontalmente saudáveis, entre 2 e 13 anos. A técnica da PCR foi utilizada para detectar as seguintes bactérias: $P$. gingivalis, $B$. forsythus, $P$. intermedia, P. nigrescens, C. rectus, E. corrodens, $A$. actinomycetemcomitans, C. ochracea, Capnocytophaga sputigena e T. denticola. Os resultados indicaram que C. rectus, E. corrodens, $A$. actinomycetemcomitans, C. ochracea e C. sputigena foram encontradas em cerca de $50 \%$ das amostras de placa em todas as idades, enquanto que $B$. forsythus e $P$. intermedia foram detectadas menos freqüentemente, e $P$. gingivalis e T. denticola não foram encontradas. Em contraste, a porcentagem de indivíduos positivos para $P$. nigrescens aumentou com a idade na dentição decídua, alcançando cerca de 50\% em crianças com 7 anos ou mais.

MAYANAGI et al. ${ }^{32}$, em 2004, compararam as freqüências de detecção, por meio da PCR, de 25 espécies bacterianas nas placas subgengival e supragengival de 18 indivíduos com periodontite não tratada e de 12 periodontalmente saudáveis. Catorze espécies não apresentaram relação com a periodontite. Nove, dentre as quais $P$. intermedia e $T$. denticola, pareceram estar relacionadas com esta doença; suas freqüências de detecção em amostras de placa subgengival foram maiores em indivíduos com periodontite do que naqueles saudáveis, embora esta 
diferença não tenha sido estatisticamente significativa. Duas espécies (Mogibacterium timidum e $P$. gingivalis) foram significativamente mais freqüentes na placa subgengival de indivíduos com periodontite do que naqueles saudáveis. Não houve diferenças significativas nas freqüências de detecção das 25 bactérias entre amostras de placa subgengival e supragengival.

No estudo de MALHEIROS e AVILA-CAMPOS ${ }^{29}$, em 2004, a técnica da PCR foi utilizada para detectar a presença de $A$. actinomycetemcomitans e F. nucleatum em amostras de placa subgengival. Estas bactérias foram isoladas, respectivamente, em $18 \%$ e $20 \%$ dos 50 pacientes com periodontite, e em $2 \%$ e $24 \%$ dos 50 indivíduos saudáveis.

A detecção de microrganismos periodontopatogênicos com a utilização de amostras de placa dentária tem-se mostrado bastante eficaz em estudos microbiológicos. Entretanto, muitos pesquisadores vêm utilizando amostras de saliva, as quais também parecem ser bastante úteis nestes tipos de estudo.

VON TROIL-LINDÉN et al. ${ }^{57}$, em 1995, determinaram os níveis salivares de A. actinomycetemcomitans, P. gingivalis, P. intermedia, C. rectus e Peptostreptococcus micros por meio de cultura bacteriana e relacionaram-nos com a condição clínica periodontal de 40 indivíduos divididos em três grupos (periodontite avançada, moderada e inicial ou sem a doença). Os autores também examinaram, longitudinalmente, se os níveis salivares destas bactérias eram afetados pela realização de um tratamento periodontal ou se permaneciam estáveis quando este não era realizado. Os 
resultados mostraram que indivíduos que abrigavam as 5 espécies bacterianas apresentavam números médios de $2 \times 10^{5}$ a $6 \times 10^{7}$ unidades formadoras de colônia/mL de saliva. No grupo de pacientes com periodontite inicial, A. actinomycetemcomitans não foi encontrada, e $P$. gingivalis foi detectada em apenas um dos indivíduos, enquanto ambas as espécies foram encontradas em $33 \%$ e $44 \%$, respectivamente, dos pacientes com periodontite moderada e em 60\% e 40\%, respectivamente, dos indivíduos com periodontite avançada. Observou-se também que a realização de tratamento periodontal eliminou ou reduziu os níveis salivares das bactérias por um período de 6 meses, enquanto que em pacientes não tratados, as freqüências de detecção permaneceram estáveis.

SAKAMOTO et al. ${ }^{44}$, em 2000 , compararam a microbiota bacteriana bucal na saliva de dois pacientes com periodontite e de um indivíduo periodontalmente saudável. Os genes 16S rDNAs foram amplificados por meio da PCR e, em seguida, clonados. Não foram encontradas seqüências de clones relacionadas a bactérias periodontopatogênicas na amostra de saliva do indivíduo saudável, enquanto que vários periodontopatógenos, tais como $C$. rectus, $P$. intermedia, $P$. gingivalis e Treponema socranskii, foram detectados nas amostras dos pacientes com periodontite.

O estudo realizado por SIRINIAN et al. ${ }^{49}$, em 2002, teve como objetivo determinar a freqüência de $A$. actinomycetemcomitans, $P$. gingivalis, $B$. forsythus e T. denticola na saliva de indivíduos jovens, de diferentes raças/etnias, habitantes de Los Angeles, Califórnia, e os indicadores de risco relacionados à ocorrência salivar desses 4 patógenos periodontais. Do total 
de 150 pacientes (hispânicos, caucasianos e americanos asiáticos), 15\% apresentaram A. actinomycetemcomitans, $15 \% \quad P$. gingivalis, $14 \% \quad B$ forsythus e $18 \%$ T. denticola. Nenhuma relação significativa foi identificada entre a etnia e a presença destas espécies.

UMEDA et al. ${ }^{56}$, em 1998, compararam a detecção, por meio da PCR, de seis bactérias periodontopatogênicas ( $A$. actinomycetemcomitans, $B$. forsythus, $P$. gingivalis, $P$. intermedia, $P$. nigrescens e $T$. denticola) na saliva total e na placa subgengival de 202 indivíduos. $P$. gingivalis, $P$. intermedia, $P$. nigrescens e $T$. denticola foram detectadas mais freqüentemente na saliva total do que em amostras de bolsa periodontal, enquanto que, para $A$. actinomycetemcomitans e $B$. forsythus, apenas o uso de amostras de saliva tendeu a subestimar a sua ocorrência. Assim, os autores concluíram que a saliva é igual ou melhor que as amostras de placa (das 4 bolsas mais profundas) para se detectar microrganismos periodontopatogênicos presentes na cavidade bucal.

TAKEUCHI et al. ${ }^{53}$, em 2001, tiveram como objetivo identificar $T$. socranskii, T. denticola e P. gingivalis, por meio da PCR, na placa subgengival e na saliva de 103 pacientes com periodontite e de 20 pacientes saudáveis. Além disso, procuraram elucidar a relação existente entre a presença destes microrganismos e a severidade de parâmetros clínicos periodontais, como o índice gengival, o índice de placa, a profundidade de sondagem, entre outros. Observaram que as freqüências de detecção de $T$. denticola e $P$. gingivalis foram aproximadamente as mesmas tanto em amostras de saliva quanto de placa. Entretanto, para T. socranskii, a 
freqüência de detecção bacteriana na saliva de pacientes com periodontite foi muito menor do que na placa. A prevalência destes 3 microrganismos pôde ser correlacionada com vários parâmetros clínicos.

ROSA et al. ${ }^{43}$, em 2002, procuraram avaliar a condição periodontal e a presença de periodontopatógenos em 30 mães brasileiras, com idades entre 21 e 40 anos, e em seus filhos ( 5 a 6 anos). Além de determinar alguns parâmetros clínicos (índice de placa e índice gengival de mães e filhos, e profundidade de sondagem apenas das mães), avaliaram-se amostras de placa subgengival de mães e filhos e uma amostra de saliva total das mães para detectar a presença de $A$. actinomycetemcomitans, $P$. nigrescens, $P$. gingivalis e $T$. denticola, pela técnica de "slot immunoblot". As bactérias mais prevalentes nas mães, em ordem decrescente, foram $A$. actinomycetemcomitans (100\%), P. nigrescens (93,3\%), P. gingivalis (80\%) e T. denticola (36,7\%). As crianças demonstraram padrão de higiene e de ocorrência bacteriana semelhante aos de suas mães. Além disso, em comparação com a placa subgengival, a saliva sempre exibiu os maiores valores e maior positividade, demonstrando ser um indicador de colonização bucal e poder funcionar como veículo para a transmissão de periodontopatógenos de mães para filhos.

Apesar de a saliva, comprovadamente, ser um meio adequado para a detecção de microrganismos, tem-se verificado que ela contém inibidores naturais da PCR, podendo causar resultados falso-negativos e, conseqüentemente, subestimar a presença dos microrganismos estudados. A fim de solucionar ou minimizar este problema, MÄTTO et al. ${ }^{30}$, em 1998, 
descreveram um método de processamento de amostra, com a utilização de Chelex 100, para prevenir a inibição da PCR pela saliva. A eficácia deste método de PCR para a detecção de $P$. gingivalis em amostras de saliva foi comparada com a da cultura bacteriana. Adicionalmente, o presente método de PCR foi aplicado para determinar a ocorrência de $P$. gingivalis em amostras de saliva de 263 indivíduos finlandeses com idade entre 5 e 80 anos. Os autores observaram que $P$. gingivalis foi detectada na saliva três vezes mais por PCR do que por cultura, embora tenha sido raramente detectada na saliva de crianças menores de 10 anos (5\%) e de adultos jovens. A prevalência de $P$. gingivalis aumentou com a idade, sugerindo que a colonização bucal por esta espécie bacteriana ocorre principalmente na fase adulta.

UMEDA et al. ${ }^{55}$, em 2004, investigaram a distribuição de bactérias periodontopatogênicas na cavidade bucal de crianças e de seus pais, bem como a relação entre algumas bactérias ( $A$. actinomycetemcomitans, $T$. forsythensis, C. rectus, $P$. gingivalis, $P$. intermedia, $P$. nigrescens e $T$. denticola) e parâmetros clínicos. Cinqüenta e cinco crianças, incluindo 15 com dentição decídua, 26 com dentadura mista e 15 com dentição permanente, tiveram coletadas amostras de saliva e de placa subgengival, enquanto que de seus pais foram coletadas apenas amostras de saliva. A freqüência de detecção de $T$. forsythensis, $C$. rectus, $P$. nigrescens, $T$. denticola, A. actinomycetemcomitans e $P$. gingivalis na cavidade bucal de crianças foi de $42,9 \%, 94,6 \%, 42,9 \%, 48,2 \%, 1,8 \%$ e $8,9 \%$, respectivamente. Freqüências diferentes de detecção de $P$. nigrescens foram encontradas na 
cavidade bucal de crianças com dentições decídua, mista e permanente. Além disso, crianças que abrigavam $T$. forsythensis, $P$. intermedia, $P$. nigrescens e $T$. denticola apresentaram escores mais elevados para a mensuração de detritos bucais pelo índice de higiene bucal simplificado.

Três métodos diferentes, PCR convencional, PCR em tempo real e cultura, foram comparados no estudo conduzido por SAKAMOTO et al. ${ }^{45}$, em 2001, a fim de detectar e quantificar as seguintes bactérias: $A$. actinomycetemcomitans, $B$. forsythus, $P$. gingivalis, $T$. denticola e $T$. socranskii na saliva e na placa subgengival de cinco pacientes. Houve boa concordância entre os resultados dos métodos da PCR convencional e da PCR em tempo real para todas as amostras de saliva. Bactérias periodontopatogênicas foram mais freqüentemente detectadas em amostras de saliva do que em amostras de placa subgengival, sugerindo que a saliva é igual ou melhor do que a placa para a detecção e quantificação destes microrganismos na cavidade bucal.

A técnica da PCR em tempo real tem sido bastante utilizada não apenas para detectar a presença de bactérias, mas principalmente para quantificar o seu número nos diferentes tipos de amostra. Utilizando esta técnica, YOSHIDA et al. ${ }^{61}$, em 2004, avaliaram os números relativos e absolutos de $T$. denticola na saliva e na placa subgengival e investigaram a relação entre a profundidade da bolsa periodontal e o número de bactérias neste local. Os autores encontraram uma correlação positiva significativa entre estes parâmetros, o que indica que o número e a porcentagem de $T$. denticola aumentam à medida que a bolsa se torna mais profunda. 
KUBONIWA et al. ${ }^{25}$, em 2004, utilizando PCR em tempo real, detectaram e quantificaram seis espécies bacterianas ( $P$. gingivalis, $T$. forsythensis, A. actinomycetemcomitans, $T$. denticola, $P$. intermedia e $P$. nigrescens) em amostras de placa e de detritos presentes na língua de 10 pacientes com periodontite avançada e de 10 indivíduos periodontalmente saudáveis. Todas as espécies, com exceção de $P$. nigrescens, foram detectadas em amostras de sítios doentes em números significativamente maiores do que naquelas de sítios saudáveis.

Para determinar a estabilidade da infecção por $P$. gingivalis e $A$. actinomycetemcomitans, LAMELL et al. ${ }^{26}$, em 2000, reavaliaram, por meio da PCR, após 1 a 3 anos, 101 indivíduos entre 2 e 20 anos de idade, participantes de um estudo anterior. Não se observou alteração na prevalência de ambas as bactérias; entretanto, a colonização não se manteve nos mesmos indivíduos avaliados. Os autores relataram que a colonização por estas bactérias na infância é transitória e que $P$. gingivalis parece se tornar mais estável no final da adolescência, possivelmente com o desenvolvimento de bolsas mais profundas.

OOSHIMA et al. ${ }^{40}$, em 2003, examinaram longitudinalmente a ocorrência de 10 espécies bacterianas em amostras de placa subgengival e de saliva de crianças periodontalmente saudáveis usando a PCR. C. ochracea, C. sputigena e A. actinomycetemcomitans foram freqüentemente encontradas na saliva, enquanto que $P$. gingivalis, $T$. denticola e $P$. intermedia raramente foram detectadas. $P$. nigrescens foi mais freqüentemente detectada na placa e sua prevalência aumentou com a 
idade. E. corrodens e C. rectus foram algumas vezes detectadas na saliva e na placa, enquanto que $T$. forsythensis foi ocasionalmente detectada na saliva.

Recentemente, alguns estudos têm sido realizados com o objetivo de comparar a prevalência de bactérias antes e após a realização de terapia periodontal. Desta forma, BEIKLER et al. $^{7}$, em 2004, analisaram as prevalências intra e extra-bucal de sete patógenos periodontais ( $A$. actinomycetemcomitans, $P$. gingivalis, E. corrodens, T. forsythensis, $P$. intermedia, P. nigrescens e T. denticola), por meio da PCR, em 35 pacientes com periodontite e descreveram o padrão de colonização após raspagem subgengival. Amostras de placa supra e subgengival, de saliva e de "swab" da mucosa e de sítios extra-bucais foram coletadas no início do estudo e após 6 semanas, bem como 3 e 6 meses após a terapia mecânica periodontal. A raspagem supra e subgengival diminuiu o número de sítios subgengivais infectados pelos patógenos analisados apenas transitoriamente. Entretanto, as freqüências de detecção de $T$. forsythensis, $P$. intermedia, $P$. nigrescens e $T$. denticola na região supragengival, de $P$. gingivalis, $T$. denticola e $P$. nigrescens na mucosa bucal, e de todos os patógenos com exceção de $A$. actinomycetemcomitans na saliva aumentaram ao longo do período de 6 meses de observação.

KAWADA et al. $^{20}$, em 2004, usando a técnica da PCR em tempo real, realizaram análises quantitativas de $P$. gingivalis antes e após tratamento periodontal, a fim de compreender a relação entre o número de bactérias e a condição periodontal. Os autores encontraram correlação positiva 
significativa entre a quantidade de $P$. gingivalis e a profundidade da bolsa periodontal, demonstrando que o número de células é um fator importante que afeta a progressão da doença. Além disso, houve uma redução significativa do número desta bactéria após a realização de tratamento periodontal. 
3 Proposição 


\section{PROPOSIÇÃO}

Considerando-se as divergências entre os resultados dos diversos estudos com relação à freqüência de detecção de bactérias periodontopatogênicas em crianças, e na tentativa de se verificar se os níveis de periodontopatógenos podem refletir ou não a condição periodontal destes indivíduos, propusemo-nos a avaliar:

a. A prevalência de quatro bactérias periodontopatogênicas, $A$. actinomycetemcomitans, $P$. gingivalis, $P$. nigrescens e $T$. denticola, na saliva de crianças brasileiras em fase de dentadura mista, em dois momentos distintos (com intervalo de 1 ano), utilizando a técnica da PCR;

b. A existência ou não de uma correlação entre as freqüências de detecção destas bactérias com um parâmetro clínico de saúde periodontal, estabelecido por meio do índice gengival. 
4 Material e Métodos

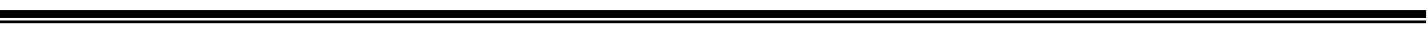




\section{MATERIAL E MÉTODOS}

O protocolo desta pesquisa foi aprovado pelo Comitê de Ética em Pesquisa da Faculdade de Odontologia de Bauru, Universidade de São Paulo (protocolo $n^{0}$ 19/2003) (Anexo 1).

\subsection{Seleção de pacientes}

Os indivíduos selecionados para este estudo foram crianças entre 8 e 10 anos de idade, provenientes da $2^{\underline{a}}$ série do ensino fundamental da Escola Estadual Professor Ayrton Busch, da cidade de Bauru, São Paulo, no ano de 2003. Os alunos não apresentavam lesões cariosas extensas, raízes residuais ou qualquer outra situação que indicasse a necessidade de extração dentária, uma vez que a escola participa de um programa de saúde bucal (restaurador e preventivo) instituído pela prefeitura do município de Bauru. Admitiram-se pacientes que não se submeteram a tratamento com antibióticos ou qualquer outra terapia medicamentosa nos 6 meses prévios ao estudo $920,32,61$, bem como não apresentavam nenhum tipo de comprometimento sistêmico ${ }^{4,36}$. A inclusão dos pacientes na amostra foi definida pela presença concomitante de dentes decíduos e dentes permanentes na cavidade bucal, caracterizando a fase de dentadura mista. Somente participaram da pesquisa pacientes cujos pais e/ou responsáveis deram seu consentimento por escrito (Anexo 2). Nesta primeira etapa do trabalho, o número total de pacientes envolvidos foi de 64 . 
Após um ano, os mesmos pacientes foram reavaliados, estando agora distribuídos em diversas escolas do município de Bauru (25 crianças na E. E. Prof. Ayrton Busch, 29 na E. E. Parque Jaraguá, 3 na E. E. Vereador Antônio Ferreira de Menezes, 1 na E. E. Salvador Filardi, 1 na E. M. E. F. Geraldo Arone e 1 na E. E. Marta Aparecida Henrique Barbosa). Nesta fase, em virtude de mudança de cidade, houve uma perda de 4 crianças na amostra da pesquisa, estando agora constituída de 60 pacientes.

Assim, todos os procedimentos descritos a seguir foram realizados nas duas etapas do trabalho (novembro de 2003 e novembro de 2004).

\subsection{Anamnese}

Foi realizada na presença dos pais e/ou responsáveis e constou de questionamentos que pudessem revelar dados sobre a saúde geral do paciente, bem como dados específicos sobre sua condição bucal (Anexo 3). Caso o paciente não apresentasse nenhum comprometimento sistêmico que o excluísse da participação na pesquisa, apresentou-se aos pais e/ou responsáveis o termo de consentimento para participação no estudo, o qual foi lido e explicado detalhadamente pelo entrevistador. Em caso de aceitação, solicitou-se a assinatura desse documento. 


\subsection{Coleta de saliva}

Os pacientes receberam um béquer de vidro estéril para a coleta de saliva total expectorada durante 5 minutos $^{7}$. Do béquer, pipetaram-se aproximadamente $1.500 \mu \mathrm{L}$ da saliva de cada paciente, os quais foram colocados num tubo de microcentrífuga estéril, e este, por sua vez, colocado em gelo picado para ser transportado até o laboratório das Disciplinas de Farmacologia e Fisiologia, do Departamento de Ciências Biológicas. Chegando ao laboratório, todos os tubos foram imediatamente estocados em freezer $\mathrm{a}-20^{\circ} \mathrm{C}$ até o momento da extração de DNA.

\subsection{Avaliação do índice gengival (IG)}

O exame clínico foi realizado em um consultório dentário existente na E. E. Prof. Ayrton Bush, sob condições adequadas de luminosidade, utilizando-se espátula de madeira e um espelho bucal. Para melhor visualização do tecido gengival, este foi seco com jato de ar previamente ao exame $^{28}$. Por meio do IG, a severidade da inflamação gengival foi avaliada ao redor dos dentes 16, 12 (ou 52), 24 (ou 64), 36, 32 (ou 72) e 44 (ou 84) (Anexo 4). Cada uma das porções gengivais (vestibular, lingual, mesial e distal) recebeu um dos seguintes escores, conforme a condição inflamatória apresentada: $0=$ gengiva normal; 1 = inflamação branda, com pequena mudança de cor e pouco edema, sem sangramento à palpação; 2 = inflamação moderada, vermelhidão, edema e brilho, com sangramento à 
palpação; e 3 = inflamação severa, vermelhidão acentuada, edema e ulcerações, com tendência ao sangramento espontâneo ${ }^{28,53,54}$. Este escore é denominado de IG para a área. Os valores de cada uma das quatro áreas do dente foram somados e divididos por quatro, com o intuito de se obter o IG para o dente. Finalmente, somando-se o IG para os dentes e dividindo-se por seis, obteve-se o IG para o paciente. Portanto, o índice para o paciente é a média aritmética dos escores para cada área examinada ${ }^{28}$. Desta forma, indivíduos com inflamação suave geralmente apresentam escore de 0,1 a 1,0; aqueles com inflamação moderada, entre 1,1 e 2,0; e um escore entre 2,1 e 3,0 representa uma inflamação grave $\mathrm{g}^{11,28}$.

Todos os pacientes foram avaliados por dois examinadores previamente calibrados (kappa $=0,88)$.

\subsection{Extração de DNA das amostras de saliva}

Todos os procedimentos laboratoriais foram realizados no laboratório das Disciplinas de Farmacologia e Fisiologia, do Departamento de Ciências Biológicas, sob orientação do Prof. Dr. Carlos Ferreira dos Santos.

A extração de DNA das amostras de saliva foi realizada tomando-se como base a técnica documentada por UMEDA et al. ${ }^{56}$, em 1998.

Os tubos contendo as amostras de saliva foram descongelados em gelo picado e homogeneizados em agitador (Quimis Aparelhos Científicos Ltda, Diadema, SP, Brasil). Para cada uma das amostras, pipetaram-se 500 $\mu \mathrm{L}$ de saliva, os quais foram transferidos para um novo tubo de 
microcentrífuga estéril de $1,5 \mathrm{~mL}$, sendo a saliva diluída e homogeneizada em água destilada estéril na proporção de 1:2 (volume/volume). Em seguida, as amostras foram centrifugadas a $10.000 \times \mathrm{g}$ durante 5 minutos em microcentrífuga refrigerada (Heraeus Biofuge 15R, Heraeus Equipment Ltd, Brentwood, UK) a $4^{\circ} \mathrm{C}$.

O "pellet" resultante foi, então, lavado em água destilada estéril da seguinte forma: descartou-se o sobrenadante e acrescentaram-se $1.000 \mu \mathrm{L}$ de água; os tubos foram homogeneizados no agitador e centrifugados a 10.000 x g por 5 minutos. Este processo de lavagem do "pellet" foi realizado 3 vezes para cada amostra.

O sobrenadante foi novamente descartado, e o "pellet" suspenso em $100 \mu \mathrm{L}$ de água livre de DNAse e RNAse (Qiagen gmbH, Hilden, Alemanha) e $100 \mu \mathrm{L}$ de InstaGene Matrix (Bio-Rad Laboratories, Inc., Hercules, CA, USA). Em seguida, o conteúdo deste tubo foi transferido para um tubo de microcentrífuga estéril de $0,5 \mathrm{~mL}$ e incubado a $56^{\circ} \mathrm{C}$ por 30 minutos em termociclador (Progene, Techne, Cambridge, UK). As amostras foram novamente homogeneizadas e fervidas durante 10 minutos para obtenção de DNA. Após nova centrifugação (10.000 x g por 3 minutos) para remover células não lisadas e restos celulares de tamanho grande, $170 \mu \mathrm{L}$ do sobrenadante foram pipetados para um novo tubo de microcentrífuga estéril para posterior análise por PCR. 


\subsection{Reação em cadeia da polimerase (PCR)}

A detecção bacteriana pela técnica da $\mathrm{PCR}$, realizada no termociclador PTC-100 Programmable Thermal Controller (MJ Research, Inc., Watertown, MA, USA), baseou-se na amplificação das seqüências dos genes $16 \mathrm{~S}$ rDNA $^{4,51}$. Todas as reações foram realizadas em duplicata num volume total de $50 \mu \mathrm{L}$, em tubos de microcentrífuga de $0,5 \mathrm{~mL}$, com os seguintes reagentes: $10 \mu \mathrm{L}$ do molde de DNA descrito acima, $5 \mu \mathrm{L}$ de $10 \mathrm{x}$ tampão para PCR (Gibco/BRL, Life Technologies, Inc., Gaithersburg, MD, USA), 1,25 unidades de Taq DNA polymerase (Lab Trade do Brasil Ltda., São Paulo, SP, Brasil), 0,2 mM de cada um dos desoxirribonucleotídeos (Gibco/BRL), 1,0 $\mathrm{MM}$ de cada primer (Integrated DNA Technologies, Inc, Coralville, IA, USA), e 1,5 mM de $\mathrm{MgCl}_{2}$ (Gibco/BRL). A mistura para reação da PCR foi coberta com óleo mineral 100\% puro (Indústria Farmacêutica Rioquímica Ltda, São José do Rio Preto, SP, Brasil).

Primers universais que se anelam a quase todas as porções $16 \mathrm{~S}$ do DNA ribossômico de bactérias, mas não às seqüências $18 S$ de células eucarióticas, foram usados como controle positivo para a amplificação por $\mathrm{PCR}^{4,51}$. Para cada par de primer, foi realizada uma reação de $\mathrm{PCR}$, substituindo-se o molde de DNA extraído previamente pela mesma quantidade de água estéril, a fim de se checar possíveis contaminações dos primers (controle negativo).

As especificidades de todos os primers foram confirmadas usando-se o programa BLAST do National Center for Biotechnology Information Server 
(http://ncbi.nlm.nih.gov/blast/), o qual verifica se os primers utilizados se hibridizam exclusivamente com regiões que conferem a identidade da bactéria procurada, ou seja, se há $100 \%$ de homologia entre os pares de primers e a dupla fita do DNA bacteriano. As seqüências de todos os primers utilizados podem ser vistas na Tabela 1.

TABELA 1 - Primers utilizados na PCR para as diferentes bactérias-alvo e tamanhos antecipados dos produtos de amplificação.

\begin{tabular}{|c|c|c|c|}
\hline Bactéria-alvo & Par de primers (5'-3') & $\begin{array}{c}\text { Tamanho } \\
\text { antecipado }\end{array}$ & $\begin{array}{c}\text { Posição das } \\
\text { bases }\end{array}$ \\
\hline A. actinomycetemcomitans & $\begin{array}{c}\text { ATGCCAACTTGACGTTAAAT } \\
\text { AAACCCATCTCTGAGTTCTTCTTC }\end{array}$ & $557 \mathrm{pb}$ & $478-1034$ \\
\hline P. gingivalis & $\begin{array}{l}\text { AGGCAGCTTGCCATACTGCG } \\
\text { ACTGTTAGCAACTACCGATGT }\end{array}$ & $404 \mathrm{pb}$ & $729-1132$ \\
\hline P. nigrescens & $\begin{array}{l}\text { ATGAAACAAAGGTTTTCCGGTAAG } \\
\text { CCCACGTCTCTGTGGGCTGCGA }\end{array}$ & $804 \mathrm{pb}$ & 219-1022 \\
\hline T. denticola & $\begin{array}{l}\text { TAATACCGAATGTGCTCATTTACAT } \\
\text { TCAAAGAAGCATTCCCTCTTCTTCTTA }\end{array}$ & $316 \mathrm{pb}$ & $193-508$ \\
\hline Primers universais* & $\begin{array}{l}\text { GATTAGATACCCTGGTAGTCCAC } \\
\text { CCCGGGAACGTATTCACCG }\end{array}$ & $602 \mathrm{pb}$ & $786-1387$ \\
\hline
\end{tabular}

*Com base na seqüência de nucleotídeos da $E$. coli ${ }^{4}$.

O processo de ciclagem térmica para as bactérias $P$. gingivalis e $T$. denticola consistiu de uma fase inicial de desnaturação por 2 minutos a $95^{\circ} \mathrm{C}$, seguida de 36 ciclos de amplificação. Cada ciclo apresentou as fases de desnaturação (30 segundos a $95^{\circ} \mathrm{C}$ ), anelamento (1 minuto a $60^{\circ} \mathrm{C}$ ) e extensão (1 minuto a $72^{\circ} \mathrm{C}$ ). As amostras foram incubadas por um período 
adicional de 2 minutos a $72^{\circ} \mathrm{C}$ (extensão final) após o término do último ciclo. Já para as bactérias $A$. actinomycetemcomitans e $P$. nigrescens, o perfil de temperatura da $\mathrm{PCR}$ incluiu uma desnaturação inicial a $95^{\circ} \mathrm{C}$ por 2 minutos, seguida de 36 ciclos a $94^{\circ} \mathrm{C}$ durante 30 segundos, $55^{\circ} \mathrm{C}$ durante 1 minuto e $72^{\circ} \mathrm{C}$ durante 2 minutos, e uma fase final a $72^{\circ} \mathrm{C}$ por 10 minutos $s^{4,55,56}$.

\subsection{Eletroforese horizontal}

Os produtos da PCR foram analisados por meio de uma eletroforese horizontal em gel de agarose a 2,0\%.

Para o preparo do gel, foram utilizados $40 \mathrm{~mL}$ de solução tamponada composta por Trisma base, ácido bórico e EDTA (TBE 1x), 0,8 g de agarose e $2 \mu \mathrm{g}$ de brometo de etídio $(0,5 \mu \mathrm{g} / \mathrm{mL})$. Montou-se, então, o sistema de eletroforese horizontal (Loccus biotecnologia, São Paulo, SP, Brasil), no qual despejou-se a mistura e adicionou-se o pente. Após a polimerização do gel (aproximadamente 30 minutos), o pente foi retirado, e o gel coberto com tampão para eletroforese (TBE 1x).

Em seguida, iniciou-se o carregamento do gel com uma alíquota de 9 $\mu \mathrm{L}$ de cada amostra submetida à PCR, acrescida de 1,8 $\mu \mathrm{L}$ de tampão de carregamento (azul de bromofenol e glicerol). Em uma das extremidades do gel, também foi utilizada uma alíquota de $1 \mu \mathrm{L}$ de padrão de peso molecular, acrescida de 1,8 $\mu \mathrm{L}$ de tampão de carregamento e $8 \mu \mathrm{L}$ de água destilada estéril. A eletroforese foi realizada com a aplicação de corrente de $200 \mathrm{~V}$ durante 2 horas. 
Após a eletroforese, o gel de agarose foi colocado sobre um transiluminador ultravioleta (T 2202, Sigma Chemical Company, St. Louis, MO, USA), realizando-se, imediatamente, a fotodocumentação para registro da presença de produtos amplificados de tamanhos antecipados. O peso molecular dos produtos da PCR foi determinado pela comparação com um marcador de peso molecular de 100 pb (Gibco/BRL).

\subsection{Análise estatística}

Para a análise dos dados, as crianças foram consideradas positivas para uma determinada bactéria se esta estivesse presente em pelo menos uma das amostras submetidas à PCR em duplicata. Realizou-se, então, uma análise descritiva de todos os dados obtidos em novembro de 2003 e novembro de 2004 separadamente, e os resultados foram avaliados pelo teste exato de Fisher, com o intuito de se verificar possíveis associações entre a condição de inflamação gengival (leve, moderada ou grave) e a prevalência de cada uma das quatro bactérias estudadas, bem como das combinações entre elas. Em seguida, para a determinação de diferenças significativas entre um ano e outro, foram utilizados os testes de Wilcoxon e de McNemar, para análise da variação tanto do IG como da presença de cada uma das bactérias, respectivamente. O teste de McNemar também foi utilizado com o intuito de se verificar possíveis variações significativas entre as condições de inflamação gengival apresentadas nos anos de 2003 e de 2004. A significância estatística foi estabelecida em 5\%. 
5 Resultados

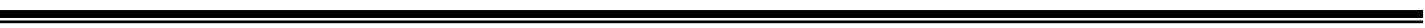




\section{RESULTADOS}

Todos os resultados são mostrados como freqüência relativa (\%), seguida pela freqüência absoluta (número) entre parênteses.

\subsection{Primeira avaliação: novembro de 2003}

Do total de 64 crianças avaliadas em novembro de 2003, 96,9\% (62) apresentaram baixa inflamação gengival, e 3,1\% (2) tiveram escores moderados. O valor médio \pm desvio padrão para o IG foi $0,856 \pm 0,133$, e a mediana foi 0,875 .

Os resultados da PCR indicaram que 18,8\% (12) das crianças não apresentaram nenhuma das quatro bactérias estudadas. A prevalência de cada uma das espécies e da combinação de espécies nesta população é mostrada na Tabela 2. O resultado da PCR para a detecção de $T$. denticola, P. gingivalis, $A$. actinomycetemcomitans e $P$. nigrescens, presentes na saliva de algumas das crianças avaliadas, pode ser observado nas Figuras 1, 2, 3 e 4, respectivamente. Além disso, a Figura 5 mostra o resultado da PCR de seis crianças utilizando-se o par de primers universais.

Com relação às quatro espécies bacterianas estudas, 81,3\% (52) das crianças abrigavam pelo menos uma delas, 17,2\% (11) pelo menos duas, e 6,3\% (4) pelo menos três. Adicionalmente, 64,1\% (41) abrigavam apenas uma espécie, 10,9\% (7) duas espécies, 4,7\% (3) três, e 1,6\% (1) as quatro espécies. A Figura 6 mostra os resultados da PCR de um indivíduo que 
abrigava as quatro espécies de bactérias estudadas. Além disso, o teste exato de Fisher não mostrou associação significativa entre a condição de inflamação gengival e a prevalência de cada uma das quatro bactérias periodontopatogênicas estudadas, bem como das possíveis combinações entre elas $(p>0,05)$.

Tabela 2 - Freqüências relativa (\%) e absoluta (número entre parênteses) de A. actinomycetemcomitans, $P$. gingivalis, $P$. nigrescens e $T$. denticola, bem como da combinação entre tais espécies, nas amostras de saliva de 64 crianças no ano de 2003.

Bactéria periodontopatogênica

Freqüência

A. actinomycetemcomitans

$4,7 \%(3)$

P. gingivalis

$6,3 \%(4)$

P. nigrescens

$23,4 \%(15)$

T. denticola

$71,9 \%(46)$

A. actinomycetemcomitans e $P$. gingivalis

$1,6 \%(1)$

A. actinomycetemcomitans e $P$. nigrescens

$4,7 \%(3)$

A. actinomycetemcomitans e $T$. denticola

$4,7 \%(3)$

$P$. gingivalis e $P$. nigrescens

$3,1 \%(2)$

$P$. gingivalis e $T$. denticola

$3,1 \%(2)$

$P$. nigrescens e $T$. denticola

$17,2 \%(11)$

A. actinomycetemcomitans, $P$. gingivalis e $P$. nigrescens

$1,6 \%(1)$

A. actinomycetemcomitans, $P$. gingivalis e $T$. denticola

$1,6 \%(1)$

$A$. actinomycetemcomitans, $P$. nigrescens e $T$. denticola

$4,7 \%(3)$

$P$. gingivalis, $P$. nigrescens e $T$. denticola 


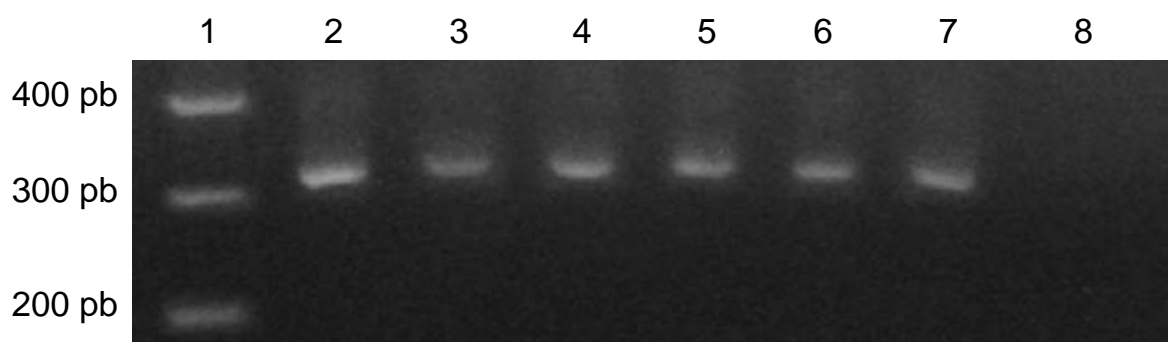

Figura 1: Gel de agarose corado com brometo de etídio dos produtos da PCR para detecção de $T$. denticola na saliva de seis crianças em novembro de 2003. Coluna 1, marcador de peso molecular de $100 \mathrm{pb}$; colunas 2-7, $T$. denticola (316 pb); coluna 8, controle negativo (água).

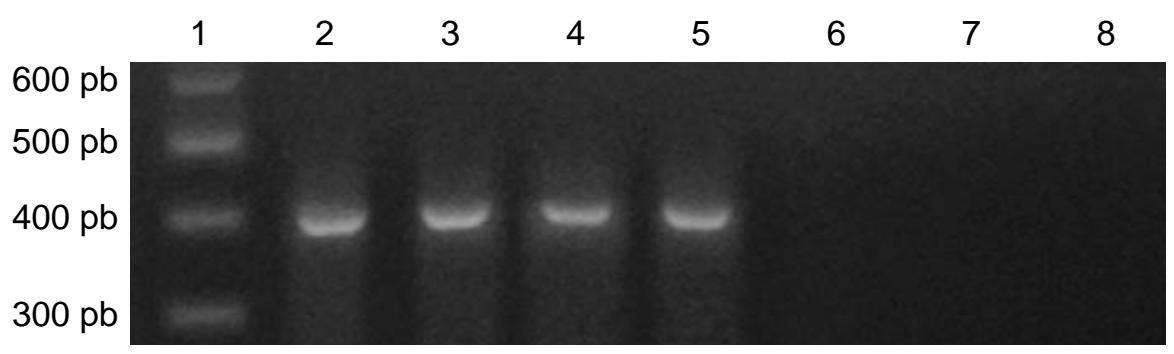

Figura 2: Gel de agarose corado com brometo de etídio dos produtos da PCR para detecção de $P$. gingivalis na saliva de seis crianças em novembro de 2003. Coluna 1, marcador de peso molecular de $100 \mathrm{pb}$; colunas 2-7, P. gingivalis (404 pb); coluna 8, controle negativo (água).

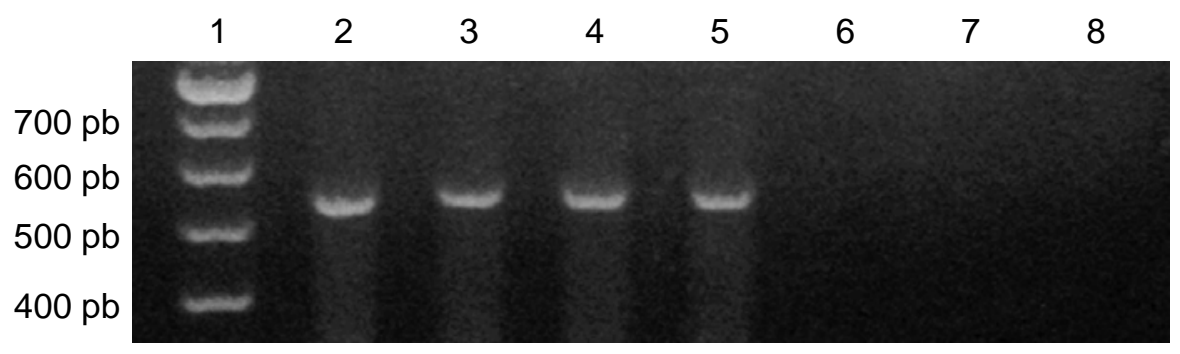

Figura 3: Gel de agarose corado com brometo de etídio dos produtos da PCR para detecção de A. actinomycetemcomitans na saliva de seis crianças 
em novembro de 2003. Coluna 1, marcador de peso molecular de 100 pb; colunas 2-7, A. actinomycetemcomitans (557 pb); coluna 8, controle negativo (água).

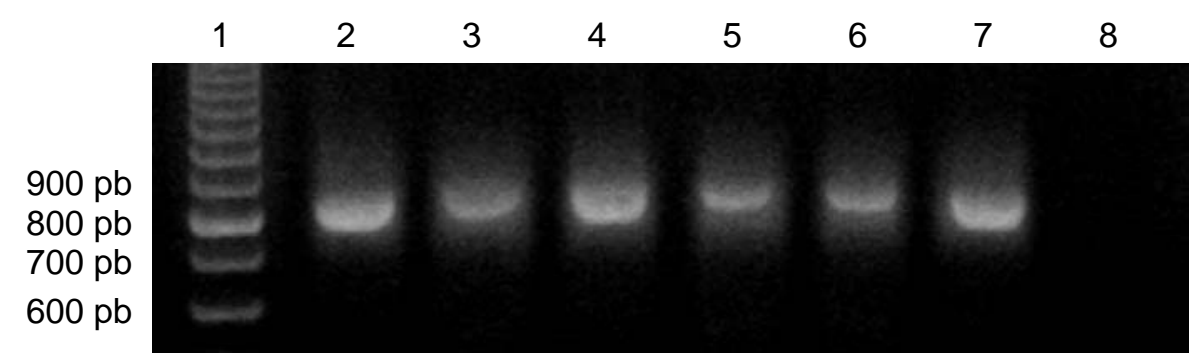

Figura 4: Gel de agarose corado com brometo de etídio dos produtos da PCR para detecção de $P$. nigrescens na saliva de seis crianças em novembro de 2003. Coluna 1, marcador de peso molecular de 100 pb; colunas 2-7, P. nigrescens (804 pb); coluna 8, controle negativo (água).

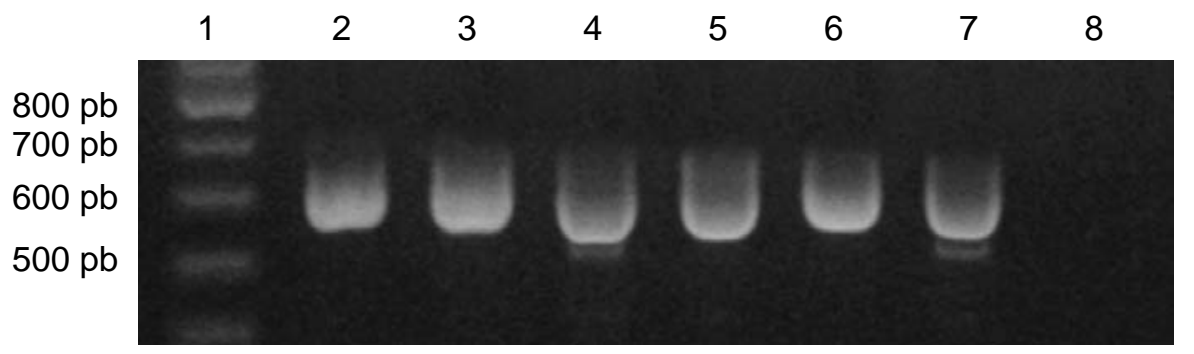

Figura 5: Gel de agarose corado com brometo de etídio dos produtos da PCR utilizando-se primers universais na saliva de seis crianças em novembro de 2003. Coluna 1, marcador de peso molecular de 100 pb; colunas 2-7, primers universais (602 pb); coluna 8, controle negativo (água). 


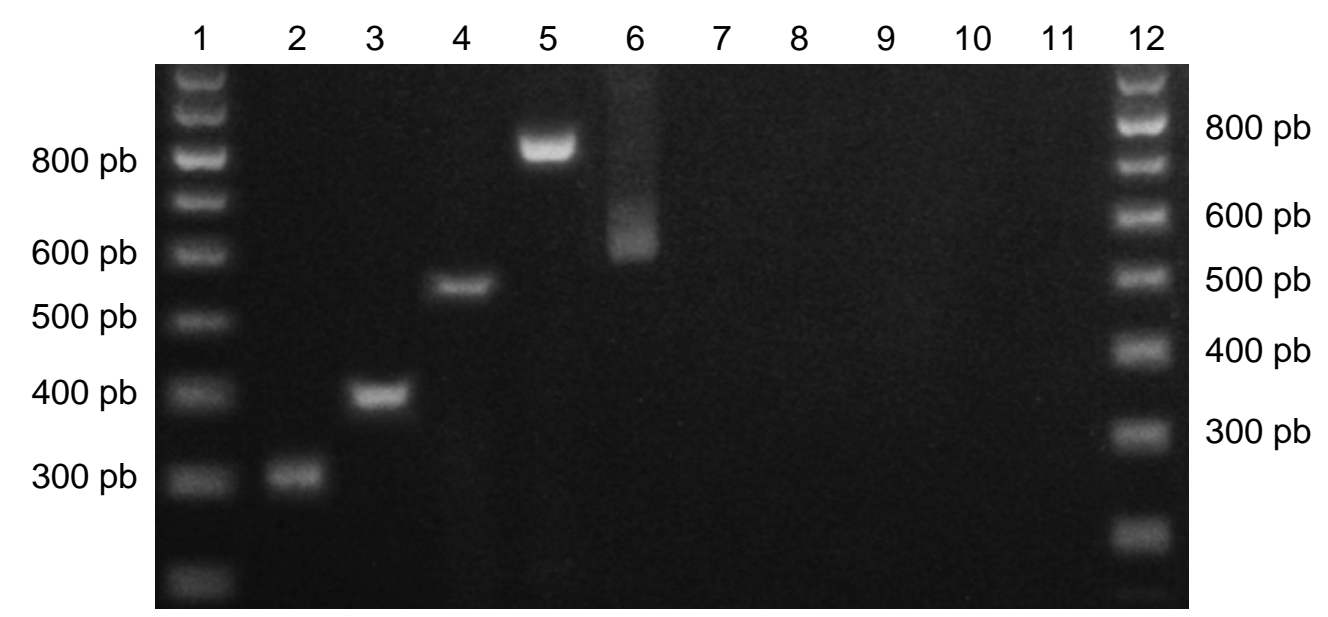

Figura 6: Gel de agarose corado com brometo de etídio dos produtos da PCR de diferentes patógenos periodontais presentes na saliva de uma criança em novembro de 2003. Colunas 1 e 12, marcador de peso molecular de $100 \mathrm{pb}$; colunas 2-6, T. denticola (316 pb), P. gingivalis (404 pb), A. actinomycetemcomitans (557 pb), P. nigrescens $(804 \mathrm{pb})$ e primers universais (controle positivo, 602 pb), respectivamente; colunas 7-11, controle água para $T$. denticola, $P$. gingivalis, $A$. actinomycetemcomitans, $P$. nigrescens e primers universais, respectivamente.

\subsection{Segunda avaliação: novembro de 2004}

Do total de 60 crianças avaliadas em novembro de 2004, 83,3\% (50) apresentaram baixa inflamação gengival, enquanto que 16,7\% (10) tiveram escores moderados. O valor médio \pm desvio padrão para o IG foi $0,992 \pm$ 0,094 .

Os resultados da PCR indicaram que 26,7\% (16) das crianças não apresentaram nenhuma das quatro bactérias estudadas. A prevalência de 
cada uma das espécies e da combinação de espécies nesta população é mostrada na Tabela 3.

Tabela 3 - Freqüências relativa (\%) e absoluta (número entre parênteses) de A. actinomycetemcomitans, $P$. gingivalis, $P$. nigrescens e $T$. denticola, bem como da combinação entre tais espécies, nas amostras de saliva de 60 crianças no ano de 2004.

\begin{tabular}{cc}
\hline Bactéria periodontopatogênica & Freqüência \\
\hline A. actinomycetemcomitans & $1,7 \%(1)$ \\
P. gingivalis & $8,3 \%(5)$ \\
P. nigrescens & $48,3 \%(29)$ \\
T. denticola & $50,0 \%(30)$ \\
A. actinomycetemcomitans e P. gingivalis & $0,0 \%(0)$ \\
A. actinomycetemcomitans e P. nigrescens & $0,0 \%(0)$ \\
A. actinomycetemcomitans e T. denticola & $0,0 \%(0)$ \\
P. gingivalis e P. nigrescens & $5,0 \%(3)$ \\
P. gingivalis e T. denticola & $5,0 \%(3)$ \\
$P$. nigrescens e $T$. denticola & $28,3 \%(17)$ \\
A. actinomycetemcomitans, P. gingivalis, P. nigrescens e T. denticola & $0,0 \%(0)$ \\
\hline P. gingivalis, P. nigrescens e T. denticola & $0,0 \%(0)$ \\
A. actinomycetemcomitans, P. gingivalis e P. nigrescens & $0,0 \%(0)$ \\
A. actinomycetemcomitans, P. nigrescens e T. denticola & $0,0 \%(0)$ \\
\hline
\end{tabular}


Com relação às quatro espécies bacterianas estudas, 73,3\% (44) das crianças abrigavam pelo menos uma delas, $31,7 \%$ (19) pelo menos duas, e 3,3\% (2) pelo menos três. Adicionalmente, 41,7\% (25) abrigavam apenas uma espécie, 28,3\% (17) duas espécies, 3,3\% (2) três, e nenhuma das crianças abrigava as quatro espécies concomitantemente.

A análise estatística (teste exato de Fisher) não mostrou correlação significativa entre a condição de inflamação gengival e a prevalência de cada uma das quatro bactérias periodontopatogênicas estudadas, bem como das possíveis combinações entre tais espécies bacterianas $(p>0,05)$.

\subsection{Comparação entre os resultados obtidos em novembro de 2003 e novembro de 2004}

Na comparação entre os resultados dos anos de 2003 e 2004, utilizando-se o teste de McNemar, observou-se uma variação estatisticamente significativa da condição de inflamação gengival, sendo que do total de 60 crianças, $9(15,0 \%)$ passaram de inflamação gengival leve para inflamação moderada. Além disso, por meio do teste de Wilcoxon, observou-se também um pequeno aumento dos escores do IG na maioria das crianças avaliadas, sendo esta variação estatisticamente significativa.

A concordância para a presença de $A$. actinomycetemcomitans e $P$. gingivalis na primeira e segunda avaliação pode ser vista na Figura 7 . O teste de McNemar não revelou associação significativa entre a detecção de 
cada uma destas bactérias nos dois momentos de avaliação com intervalo de um ano.

A. actinomycetemcomitans

2004

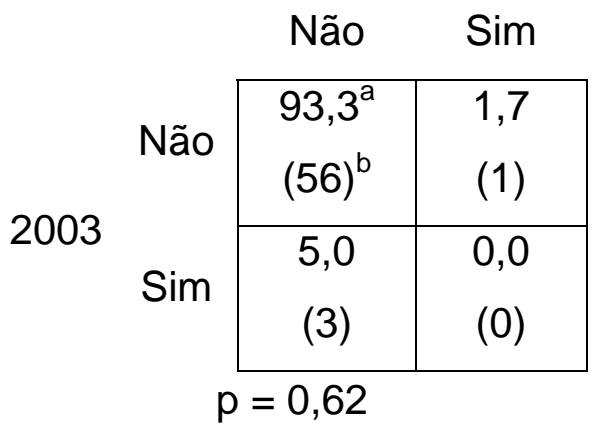

P. gingivalis

2004

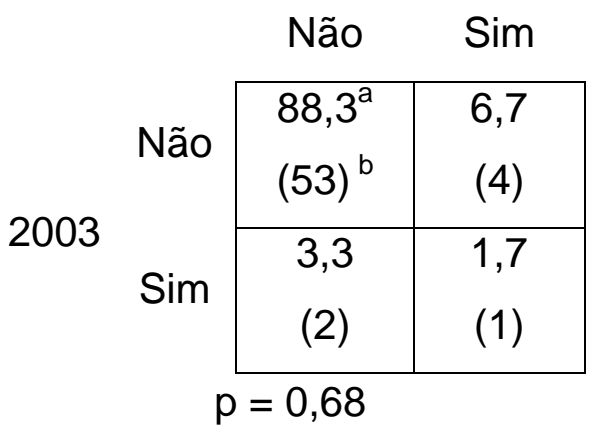

Figura 7: Matriz de concordância de colonização entre as avaliações de 60 crianças nos anos de 2003 e 2004 para A. actinomycetemcomitans e $P$. gingivalis. a, porcentagem de crianças em relação ao total; b (valores entre parênteses), número de crianças avaliadas.

Já a concordância para a presença de $P$. nigrescens e $T$. denticola nas duas avaliações (novembro de 2003 e novembro de 2004) pode ser vista na Figura 8. O teste de McNemar indicou variações estatisticamente significativas tanto de aumento do número de crianças que abrigavam $P$. nigrescens na cavidade bucal, quanto de diminuição do número de crianças com T. denticola. 


\section{P. nigrescens}

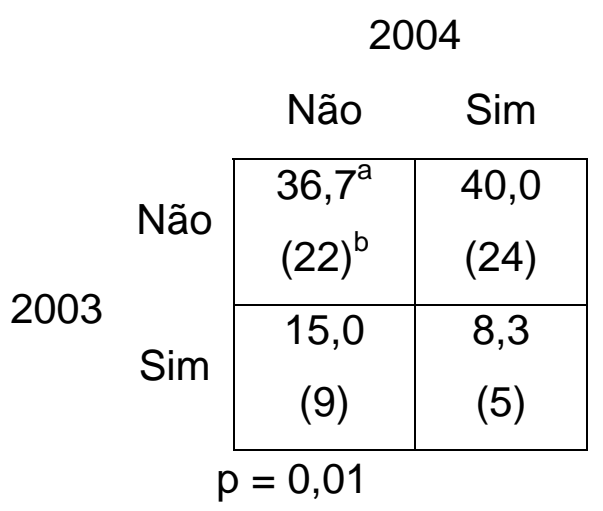

T. denticola

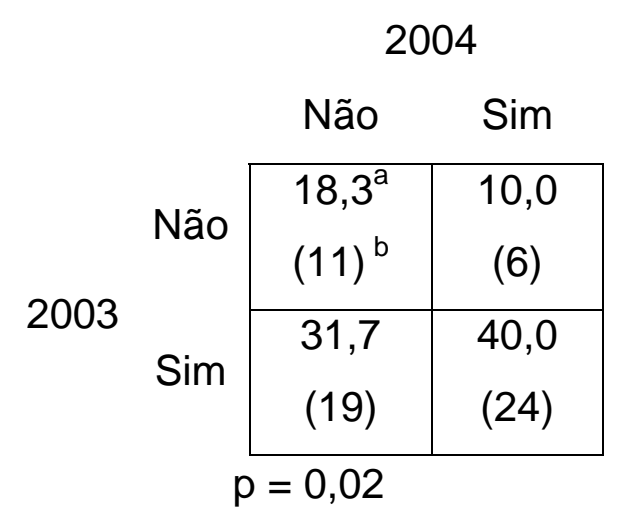

Figura 8: Matriz de concordância de colonização entre as avaliações de 60 crianças nos anos de 2003 e 2004 para P. nigrescens e T. denticola. a, porcentagem de crianças em relação ao total; b (valores entre parênteses), número de crianças avaliadas. 
6 Discussão

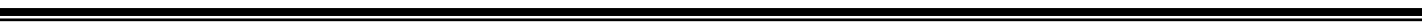




\section{DISCUSSÃO}

Atualmente, a relação entre parâmetros clínicos, tais como o índice de placa, o índice gengival ou a profundidade de sondagem, e a distribuição de várias bactérias periodontopatogênicas em indivíduos de diferentes idades ainda não é bem compreendida. Desta forma, este estudo procurou determinar se a presença de $A$. actinomycetemcomitans, $P$. gingivalis, $P$. nigrescens e $T$. denticola na saliva de crianças em fase de dentadura mista poderia ser correlacionada à severidade da inflamação gengival determinada pelo IG. Além disso, a fim de se verificar a estabilidade da colonização destas bactérias, após um ano todas as crianças foram reavaliadas.

\subsection{A respeito dos métodos empregados}

Devido à etiologia microbiana da periodontite, parece razoável admitir que um exame microbiológico periodontal pode ajudar tanto a identificar os agentes causadores da doença como a estabelecer uma intervenção terapêutica apropriada. Quando usados adequadamente, testes de diagnósticos microbiológicos podem ser úteis nas seguintes situações: identificação de fatores de risco para a doença, avaliação da severidade da doença, estimativa do prognóstico, seleção e ajuste de terapias e seleção de drogas antimicrobianas ${ }^{50}$.

Atualmente, métodos de diagnósticos microbiológicos são altamente complexos e especializados. Cada um dos testes de diagnósticos 
comumente utilizados para identificação de microrganismos tem suas vantagens e limitações ${ }^{47,50}$. Métodos de cultura detectam apenas bactérias capazes de se estabelecer no meio de cultura, e os resultados para microrganismos presentes em pequenas quantidades não podem ser obtidos ou não são rapidamente alcançados. A técnica de hibridização do DNA, com utilização de testes disponíveis comercialmente, requer um mínimo de 6 x $10^{3}$ microrganismos para a obtenção de resultado positivo. Assim, a hibridização pode não detectar níveis sub-clínicos de infecção ${ }^{59,60}$. Embora os métodos de cultura e de hibridização apresentem certo grau de sensibilidade, ambas as técnicas são muito trabalhosas e requerem considerável conhecimento e gasto financeiro, o que limita sua aplicação universal. Técnicas imunológicas e enzimáticas também são disponíveis para a detecção de bactérias, não dependendo de sua viabilidade na amostra. Entretanto, testes enzimáticos não são úteis para detectar espécies bacterianas individuais, enquanto que testes imunológicos requerem amostras suficientemente grandes para a detecção de bactérias específicas e para cada controle. A vantagem da PCR, em comparação com outros métodos, é que esta técnica é relativamente simples, pode ser utilizada para identificar a presença de bactérias em uma amostra em menos de quatro horas e é extremamente sensível. Assim, a PCR pode ser usada para se determinar rapidamente a presença de um número extremamente baixo de prováveis patógenos em múltiplos sítios de um mesmo paciente e, mais importante ainda, para determinar alterações no número de patógenos num 
mesmo sítio ao longo do tempo ${ }^{60}$. Devido a todas estas vantagens da PCR em detrimento das demais, decidimos aplicar esta técnica em nosso estudo.

Embora a PCR apresente excelentes limites de detecção, uma quantidade relativamente pequena de toda a amostra é usada no processo de amplificação. Portanto, a alíquota para a PCR pode não incluir os microrganismos-alvo se estes estiverem presentes em baixas concentrações $^{8}$. A fim de minimizar este problema, todas as nossas reações de PCR foram realizadas em duplicata, e as crianças foram consideradas positivas para uma determinada bactéria quando esta estava presente em pelo menos uma das duas amostras.

Para a realização da PCR, é fundamental que o processo de extração do DNA seja adequadamente conduzido, de acordo com o tipo de amostra que se dispõe. No caso de amostras de saliva, conforme a descrição de UMEDA et al. $^{56}$, em 1998, este processo se baseia em lavagens e centrifugações repetidas, cujos objetivos principais são remover possíveis inibidores da PCR e permitir uma diminuição no limite de detecção das células-alvo. Contudo, seguindo este protocolo e realizando posteriormente a técnica da PCR inúmeras vezes, não conseguimos obter resultado positivo para nenhuma das amostras estudadas, inclusive com a utilização dos primers universais (dados não mostrados). Este fato nos sinalizou para um possível problema na etapa de extração de DNA, provavelmente devido à permanência de inibidores naturais da PCR presentes na saliva, os quais não puderam ser removidos exclusivamente por meio de lavagens e centrifugações sucessivas. 
CONRADS et al. ${ }^{10}$, em 1996, já relatavam que uma baixa concentração de bactérias-alvo (<500 células) e/ou compostos inibitórios, tais como cátions, poderiam causar resultados falso-negativos como observados em seu estudo. Considerando-se que a saliva, um material de origem biológica, pode conter moléculas que inibem a polimerização do DNA bacteriano, ou que se liguem ao DNA bacteriano e/ou aos primers de maneira não específica, fez-se necessário em nosso experimento a utilização de uma matriz comercial de purificação de DNA, a fim de favorecer a sensibilidade na detecção dos microrganismos sem perda de especificidade. Isto porque a inibição não pode ser superada pelo aumento na quantidade de primers, uma vez que isto também favorece 0 aparecimento de bandas referentes a outras bactérias presentes na microbiota bacteriana normal da cavidade bucal $^{58}$, nem pelo aumento na quantidade de DNA na reação de PCR, já que desta forma também são introduzidos mais inibidores desta reação ${ }^{30}$.

Assim, para confirmar nossa suspeita, realizamos outros experimentos, agora com o uso de Chelex 100 (Bio-Rad Laboratories, Inc., Hercules, CA, USA) para a extração do DNA, uma vez que este produto tem a capacidade de quelar íons bivalentes, favorecendo a eficiência da extração do DNA e protegendo o DNA em altas temperaturas ${ }^{9,30,40}$. Com a utilização deste produto, obtivemos algumas bandas referentes aos alvos procurados, embora ainda fossem fracas e de difícil visualização (dados não mostrados). No entanto, a pesquisadora finlandesa Jaana Mättö (jaana.matto@vtt.fi), em 
contato com o co-orientador deste trabalho, sugeriu-nos a utilização de InstaGene Matrix, uma versão mais avançada daquele produto (Anexo 5).

Desta forma, InstaGene Matrix foi utilizado, primeiramente de acordo com as instruções do fabricante ${ }^{32}$, obtendo-se resultados positivos em todas as reações de PCR realizadas com primers universais (dados não mostrados), o que confirmou nossas suspeitas quanto à presença de inibidores naturais da PCR na saliva. Entretanto, consideramos que o volume deste produto recomendado pelo fabricante (200 $\mu \mathrm{L})$ no processo de extração do DNA era muito grande, o que nos levou a realizar novos testes. Assim, utilizamos $100 \mu \mathrm{L}$ de InstaGene Matrix acrescidos de $100 \mu \mathrm{L}$ de água destilada estéril, e novamente obtivemos resultados positivos para todas as amostras testadas nas reações de PCR com primers universais, sem perda considerável de qualidade na visualização das bandas (dados não mostrados). Assim sendo, tais volumes foram estabelecidos como ideais para a extração de DNA.

Ainda conforme o preconizado pelo fabricante, para um volume total de $50 \mu \mathrm{L}$ de reação de PCR, o volume de sobrenadante (molde de DNA) requerido é de $20 \mu \mathrm{L}$. Contudo, mais uma vez observamos que este volume era excessivo, visto que, de acordo com o trabalho de UMEDA et al. ${ }^{56}$, realizado em 1998, a quantidade necessária de molde de DNA para a PCR é de $5 \%$ do volume final do tubo de reação para extração de DNA a partir de amostras de saliva. Assim, um volume de $20 \mu \mathrm{L}$ representaria $10 \%$ do DNA extraído, o que significa colocar uma quantidade muito maior de material genético para um mesmo volume de reação (50 $\mu \mathrm{L})$. Dados evidenciam que, 
ao se utilizar 5\% do DNA extraído, o método da PCR é capaz de detectar microrganismos-alvo que compreendem entre 0,02 a $0,0002 \%$ da microbiota da saliva (2.000 a 20.000 células-alvo em uma amostra de saliva contendo um total de bactérias cultiváveis de $10^{8}$ a $10^{9} / \mathrm{mL}$ ). Além disso, tendo um limite de detecção de 2.000 a 20.000 células $/ \mathrm{mL}$, a PCR é útil na determinação da presença bucal de bactérias periodontopatogênicas, cujos níveis médios na saliva variam de $10^{5}$ a $10^{7}$ células $/ \mathrm{mL}$ em pacientes com periodontite ${ }^{56,57}$.

Desta forma, parece óbvio que, ao se utilizar um volume maior de DNA para a realização da PCR, também se estaria utilizando uma maior concentração de microrganismos-alvo, o que elevaria a sensibilidade do método. Entretanto, este aumento da sensibilidade não é desejável em estudos microbiológicos que visam identificar indivíduos com níveis significativos de patógenos potenciais ${ }^{56}$, uma vez que detectaríamos microrganismos presentes na cavidade bucal em níveis extremamente reduzidos, os quais podem ser insignificantes para causar um desequilíbrio periodontal e iniciar a doença. Assim, estabelecemos que o volume do molde de DNA para cada reação deveria ser de $10 \mu \mathrm{L}$, estando, portanto, determinadas todas as condições favoráveis para a realização da PCR em nosso estudo. 


\subsection{A respeito dos resultados obtidos}

Nas avaliações clínicas realizadas tanto em 2003 como em 2004, observaram-se apenas manifestações leves e moderadas de inflamação gengival, o que está de acordo com os resultados encontrados na literatura para crianças de diferentes idades, níveis sócio-econômicos e grupos étnicos ${ }^{11,52}$. Segundo JENKINS e PAPAPANOU ${ }^{18}$, em 2001, e ALBANDAR e TINOCO ${ }^{2}$, em 2002, formas de inflamação gengival leve e moderada são um achado praticamente universal em indivíduos jovens.

Além disso, de acordo com nossos resultados, o valor médio do IG $(0,856 \pm 0,133$ em 2003 e 0,992 $\pm 0,094$ em 2004) foi relativamente baixo, uma vez que nossa amostra consistiu de crianças saudáveis. TAKEUCHI et al. ${ }^{53}$, em 2001, também avaliaram pacientes adultos saudáveis por meio do IG, encontrando ausência de inflamação gengival nesta população.

Na comparação de nossos resultados nos anos de 2003 e de 2004, observou-se que, de um ano para o outro, houve uma variação estatisticamente significativa da condição da inflamação gengival, bem como um aumento dos escores do IG na maioria das crianças avaliadas. Contudo, esta pequena variação em um único parâmetro clínico em crianças é insuficiente para considerar a existência de uma possível relação direta entre o aumento da idade e a piora da condição gengival, mesmo porque o intervalo entre as avaliações foi de apenas um ano. Desta forma, avaliações futuras são necessárias para se confirmar ou não tal relação. TANAKA et al. ${ }^{54}$, em 2002, afirmaram que estudos anteriores que utilizaram parâmetros 
clínicos, tais como índice de placa, índice gengival e profundidade de sondagem, mostram uma tendência de piora da condição periodontal com o aumento da idade na população geral e em adultos sistemicamente saudáveis. Além disso, em pacientes com periodontite crônica, TAKEUCHI et al. $^{53}$, em 2001, observaram que, à medida que os escores do IG aumentavam, havia também um aumento de sítios de bolsa periodontal positivos para bactérias periodontopatogênicas.

Um dos aspectos principais da prevenção da doença periodontal é a identificação de indivíduos com risco elevado, e um dos indicadores de risco corresponde à presença de potenciais periodontopatógenos ${ }^{11}$. Desta forma, mesmo a gengivite sendo considerada comum em crianças, seu monitoramento na infância, por meio da detecção precoce de microrganismos associados à doença, pode ter um impacto considerável na prevenção, possibilitando o controle ou a eliminação da doença periodontal em adultos ${ }^{36}$. Isto porque o conhecimento sobre a aquisição e o estabelecimento de patógenos periodontais pode ajudar a elucidar a história natural do desenvolvimento da periodontite e fornecer valiosas informações para o estabelecimento de estratégias preventivas da doença ${ }^{26}$. Obviamente, não há prova direta de que a colonização infantil por estas bactérias possa predispor o indivíduo à periodontite do adulto. Entretanto, quanto mais cedo ocorre a infecção, maior a oportunidade de os microrganismos se estabelecerem naquele nicho ${ }^{36}$.

Assim, a natureza da infecção e a transmissão de bactérias periodontopatogênicas de hospedeiro para hospedeiro correspondem a 
tópicos essenciais sobre a microbiologia periodontal. Segundo SLOTS ${ }^{50}$, em 1999, as bactérias presentes na cavidade bucal podem ser exógenas, isto é, causam infecções verdadeiras e são transmissíveis entre indivíduos expostos, ou podem ser meramente microrganismos indígenas que se multiplicam e dão origem a infecções endógenas em indivíduos com defesa insuficiente. Esta diferenciação entre periodontopatógenos exógenos ou endógenos é muito importante, uma vez que a natureza da infecção pode influenciar significantemente no tratamento da doença. Um patógeno exógeno pode ser completamente eliminado da cavidade bucal, enquanto que um patógeno indígena pode apenas ter seu número reduzido por intervenções mecânicas e/ou químicas. Esta diferenciação, entretanto, é bastante complexa, não tendo sido estabelecida completamente para as bactérias periodontopatogênicas ${ }^{50}$. Portanto, novas pesquisas são necessárias para delinear a natureza infecciosa desses microrganismos.

Além disso, a doença periodontal destrutiva aparentemente é o resultado de uma relação complexa entre membros da microbiota subgengival e fatores não relacionados à presença bacteriana, especificamente fatores ambientais e do hospedeiro. A presença de bactérias periodontopatogênicas, portanto, quando em combinação com um hospedeiro debilitado ou com um fator ambiental que aumenta a suscetibilidade do hospedeiro à infecção bacteriana, eleva o risco à periodontite progressiva ${ }^{17}$. Desta forma, parece ser extremamente válida a preocupação em se detectar precocemente, na cavidade bucal de crianças, bactérias periodontopatogênicas, sejam elas endógenas ou exógenas, uma 
vez que a sua presença corresponde a um indicador de risco à doença periodontal passível de ser controlado ou eliminado por meio de estratégias preventivas.

Por outro lado, a simples presença de periodontopatógenos não causa a doença, já que a transferência de microrganismos não necessariamente resulta em colonização ou infecção do hospedeiro. Indivíduos que abrigam patógenos potenciais freqüentemente não manifestam sinais de doença periodontal. Isto pode ser atribuído a diversos fatores, como: defesa do hospedeiro, antagonismo bacteriano e possível ausência de patogenicidade dos microrganismos infectantes. Entretanto, há lacunas no conhecimento da etiologia da doença periodontal, como o tempo necessário para uma infecção se estabelecer, o período de latência entre infecção e doença, e o número de bactérias (quantidade e espécies) necessário para causar uma infecção e iniciar a progressão da doença. Embora uma associação entre a prevalência de alguns patógenos periodontais e a destruição periodontal possa ser encontrada, uma relação simples de causa e efeito não tem sido mostrada para nenhuma das bactérias periodontopatogênicas ${ }^{17}$, o que justifica nossos resultados.

Das cerca de 700 espécies bacterianas encontradas na cavidade bucal $^{41}$, relativamente poucas estão correlacionadas à doença periodontal. Tem sido sugerido que, particularmente, $P$. gingivalis e $A$. actinomycetemcomitans têm um papel importante em várias formas de doença periodontal, estando muito fortemente associadas à doença ${ }^{14,41,50,55}$. Outras bactérias, dentre as quais $T$. denticola e $P$. nigrescens, estão 
relacionadas ao desarranjo periodontal como um grupo de patógenos periodontais secundários ${ }^{14,41,55}$. Além disso, bactérias periodontopatogênicas têm sido encontradas mais freqüentemente na dentadura mista do que na dentição decídua. Entretanto, como e quando estes microrganismos colonizam a cavidade bucal durante a infância ainda é incerto ${ }^{55}$.

Nossos resultados indicaram que $18,8 \%$ das crianças avaliadas em 2003 e $26,7 \%$ das crianças avaliadas em 2004 não abrigavam nenhuma das quatro bactérias periodontopatogênicas procuradas, o que está de acordo com outros estudos. KIMURA et al. ${ }^{21}$, em 2002, também observaram que $14,6 \%$ das 144 crianças avaliadas não apresentaram nenhuma das dez espécies bacterianas de interesse em seu estudo, dentre as quais estavam as quatro espécies por nós estudadas.

\subsubsection{Detecção de Porphyromonas gingivalis}

Acredita-se que uma relação etiológica entre periodontite e $P$. gingivalis, bactéria anaeróbica gram-negativa, esteja relacionada à expressão de uma variedade de prováveis fatores de virulências, embora a relação exata permaneça desconhecida. Fatores de virulência bacterianos são produtos genéticos que permitem, promovem ou modificam a habilidade dos microrganismos de causar doença no hospedeiro. $P$. gingivalis tem um armamento de produtos genéticos que interferem com a resposta imune do hospedeiro, incluindo a inativação de citocinas, paralisia de células imunes por vesículas extracelulares e modulação da resposta imune a proteínas 
relacionadas ao estresse. $P$. gingivalis também expressa um número de enzimas proteolíticas e pode modular a expressão de proteínas, fímbrias e outras adesinas associadas com sua habilidade para se ligar à célula do hospedeiro $^{48}$.

Diversos estudos que utilizam técnicas microbiológicas de cultura indicam que $P$. gingivalis não é freqüentemente encontrada em crianças, uma vez que seu ambiente bucal (fatores ambientais e nutritivos) não favorece a colonização por esta bactéria até após a puberdade $5,15,19,24$. Outros autores afirmam que crianças podem abrigar $P$. gingivalis em quantidades muito pequenas, abaixo do limiar de detecção dos meios de cultura $^{33}$.

Em nosso estudo, $P$. gingivalis foi encontrada em $6,3 \%$ e $8,3 \%$ das crianças avaliadas nos anos de 2003 e 2004, respectivamente. A baixa taxa de detecção desta bactéria está de acordo com outros estudos que empregam técnicas de biologia molecular para a detecção de microrganismos ${ }^{4,10-12,30,36,38,40,54}$. MÄTTÖ et al. ${ }^{30}$, em 1998, raramente detectaram $P$. gingivalis em crianças abaixo de 10 anos de idade (5\%), sendo também pouco encontrada em amostras de saliva de adolescentes e adultos jovens (13,4\% a $13,8 \%)$, enquanto que muitos adultos $(63,3 \%)$ acima de 30 anos de idade abrigavam esta bactéria. Da mesma forma, ASHIMOTO et al. $^{4}$, em 1996, detectaram $P$. gingivalis por PCR em apenas $14 \%$ das crianças com idade ao redor dos 7 anos, enquanto que OOSHIMA et al. ${ }^{40}$, em 2003, encontram uma taxa de detecção de 10\%. Entretanto, MCCLELLAN, GRIFFEN e LEYS ${ }^{33}$, em 1996, relataram uma alta prevalência 
de $P$. gingivalis em crianças (37\%), sendo encontrada em freqüência similar ao longo da infância e adolescência. Estes autores sugerem que $P$. gingivalis pode ser adquirida imediatamente após a exposição, possivelmente nos primeiros dias de vida.

Alguns autores têm demonstrado que a presença de $P$. gingivalis está mais fortemente associada com a progressão da gengivite e estabelecimento da periodontite na adolescência (12 anos ou mais) ${ }^{36}$, sendo que esta bactéria torna-se aparentemente mais estável no final da adolescência $^{38}$ ou em indivíduos mais velhos, possivelmente com o desenvolvimento de bolsas profundas ${ }^{26}$. Além disso, a freqüência de $P$. gingivalis pode aumentar não apenas com a severidade da doença, mas também com o aumento da idade ${ }^{54}$. DOUNGUDOMDACHA, RAWKINSON e DOUGLAS $^{12}$, em 2000, relataram que esta bactéria não tem sido encontrada em indivíduos saudáveis ou em pacientes com gengivite. Conseqüentemente, níveis elevados desse provável patógeno periodontal podem ser um indicador útil tanto de periodontite ativa quanto de risco aumentado de perda de inserção gengival.

\subsubsection{Detecção de Treponema denticola}

T. denticola, uma bactéria de formato helicoidal, é freqüentemente isolada de sítios severamente afetados pela doença periodontal, e muitos estudos têm sido realizados a fim de se elucidar o papel deste microrganismo na periodontite ${ }^{53,61}$. Recentemente, uma associação entre $T$. 
denticola e halitose tem sido fortemente indicada. Além disso, especula-se que esta bactéria pode ser relativamente fácil de ser transmitida ${ }^{55}$, podendo ser o primeiro treponema a colonizar a dentição decídua ${ }^{6}$.

A ocorrência de $T$. denticola em $71,9 \%$ e $50 \%$ das crianças avaliadas no presente estudo em 2003 e 2004, respectivamente, está de acordo com os achados de UMEDA et al. ${ }^{55}$, em 2004 , os quais detectaram a presença desta bactéria em cerca de $60 \%$ das crianças com dentadura mista avaliadas em seu estudo. BARRON, RIVIERE e SIMONSEN ${ }^{6}$, em 1991, usando anticorpos monoclonais, observaram que 50\% das crianças entre 2 e 4 anos e $70 \%$ daquelas entre 5 e 11 anos eram positivas para $T$. denticola. Além disso, ASHIMOTO et al. ${ }^{4}$, em 1996, encontraram esta bactéria em 16\% das 50 crianças entre 2 e 11 anos de idade com gengivite.

Contudo, para OKADA, HAYASHI e NAGASAKA ${ }^{39}$, em 2001, $T$. denticola raramente se estabelece na microbiota bucal de crianças periodontalmente saudáveis. Em seu estudo, avaliando crianças de 5 a 12 anos de idade, em fase de dentadura mista, detectaram $T$. denticola em $19,1 \%$ dos pacientes com gengivite e $12,5 \%$ dos pacientes com periodontite, não sendo encontrada em indivíduos saudáveis. Os resultados de prevalência para esta bactéria, portanto, são bastante discordantes, podendo sugerir uma colonização transitória. 


\subsubsection{Detecção de Actinobacillus actinomycetemcomitans}

A. actinomycetemcomitans é um cocobacilo gram-negativo que possui vários fatores de virulência. Alguns destes fatores têm a capacidade de induzir uma resposta imune intensa e/ou atrapalhar a defesa imune do hospedeiro, podendo explicar a possível patogenicidade desta bactéria. Um dos mecanismos de virulência de $A$. actinomycetemcomitans é a produção potencial de metabólitos prejudiciais, como uma leucotoxina que mata especificamente leucócitos, permitindo que a bactéria se esquive de parte das defesas do hospedeiro. Além disso, tem sido mostrado que $A$. actinomycetemcomitans é capaz de invadir células epiteliais humanas in vitro ${ }^{3}$.

Embora MORINUSHI et al. ${ }^{36}$, em 2000, tenham demonstrado uma associação entre a colonização por $A$. actinomycetemcomitans e 0 estabelecimento da gengivite na infância (3 a 7 anos), outros autores afirmam que esta bactéria raramente está presente na cavidade bucal de crianças $^{38}$, bem como não é freqüentemente encontrada em indivíduos periodontalmente saudáveis ${ }^{12}$. A. actinomycetemcomitans tem sido freqüentemente identificada em jovens com severa perda de inserção e/ou rápida progressão da doença ${ }^{3}$, bem como tem sido associada à periodontite agressiva (juvenil) $3,29,58$ e a várias infecções extra-bucais, como endocardites, pneumonias, septicemias e abscessos ${ }^{29}$.

Em nosso estudo, esta espécie bacteriana teve uma baixa prevalência nos dois anos consecutivos de avaliação (4,7\% em 2003 e 1,7\% em 2004). 
Resultados semelhantes foram obtidos por OKADA, HAYASHI e NAGASAKA ${ }^{38}$, em 2000, os quais observaram uma prevalência de $A$. actinomycetemcomitans de 4,8\% em indivíduos saudáveis e de 6,8\% em indivíduos com gengivite. Da mesma forma, UMEDA et al. ${ }^{55}$, em 2004, encontraram esta bactéria na cavidade bucal de 1,8\% das crianças avaliadas.

Contudo, a detecção de $A$. actinomycetemcomitans tem sido bastante controversa. OOSHIMA et al. ${ }^{40}$, em 2003, encontraram alta taxa de detecção (95\%), sendo esta maior em amostras de saliva (cerca de 50\%) do que de placa subgengival (cerca de 33\%). Seus achados contrastam com aqueles obtidos por UMEDA et al. ${ }^{56}$, em 1998, os quais afirmaram que apenas a taxa de detecção de $A$. actinomycetemcomitans na saliva não foi superior do que na placa dentária. KIMURA et al. $^{21}$, em 2002, também observaram, em crianças entre 2 e 13 anos divididas em grupos por faixa etária, uma alta freqüência desta bactéria (42\% a 58\%). Para LAMELL et al. ${ }^{26}$, em 2000, $A$. actinomycetemcomitans habita a cavidade bucal de crianças de qualquer idade e geralmente sua colonização é transitória, não se estabilizando com o aumento da idade.

IRFAN, DAWSON e BISSADA ${ }^{17}$, em 1999, relataram que alguns tipos de clones de $A$. actinomycetemcomitans têm uma maior relação com doença periodontal destrutiva do que outros. Assim, a ocorrência de múltiplos tipos de clones pode explicar porque certos indivíduos colonizados pela mesma espécie bacteriana podem manifestar ou não sinais de doença. Por exemplo, um teste microbiológico pode detectar elevados níveis de $A$. 
actinomycetemcomitans em um paciente saudável. Isto pode ser devido à detecção de clones não virulentos. Este fato cria um dilema, uma vez que as avaliações microbiológicas de rotina não conseguem diferenciar clones de uma mesma espécie bacteriana, nem avaliar sua patogenicidade ${ }^{14,32}$.

\subsubsection{Detecção de Prevotella nigrescens}

Com relação à $P$. nigrescens, TANAKA et al. ${ }^{54}$, em 2002, sugerem que sua presença pode estar relacionada à gengivite na puberdade ou em mulheres grávidas, uma vez que, em seu estudo, encontraram um aumento significativo da colonização desta bactéria em indivíduos entre 20 e 29 anos

de idade. Além disso, UMEDA et al. $^{55}$, em 2004, observaram que a freqüência de detecção de $P$. nigrescens foi significativamente maior em crianças com dentadura mista (cerca de 65\%) do que naquelas com dentição decídua ou permanente. Estes autores sugerem que esta bactéria pode estar associada com inflamação gengival em crianças.

Em nosso estudo, a prevalência de $P$. nigrescens foi de $23,4 \%$ na primeira avaliação e 48,3\% na segunda. MÄTTÖ et al. ${ }^{31}$, em 1996, estudando $P$. nigrescens em crianças de 2 e 3 anos, detectaram-na em quatro das seis crianças avaliadas. OOSHIMA et al. ${ }^{40}$, em 2003, observaram que esta espécie bacteriana foi primeiramente detectada em crianças de 4 anos, sendo que sua prevalência aumentou com a idade, alcançando $73 \%$ em crianças com 14 anos. Neste estudo, $P$. nigrescens foi mais freqüentemente detectada em amostras de placa do que de saliva, o que 
contrasta com outros trabalhos ${ }^{43,45,56}$. CONRADS et al. ${ }^{10}$, em 1996, também detectaram $P$. nigrescens em crianças da pré-escola até em adultos jovens com periodonto normal.

Apesar de ser considerada uma espécie bacteriana periodontopatogênica, $P$. nigrescens tem sido encontrada mais freqüentemente na margem gengival e no sulco de sítios periodontalmente saudáveis $^{39}$, não demonstrando nenhuma tendência óbvia na associação com a condição de doença periodontal ${ }^{25}$. É provável que a colonização por P. nigrescens possa ocorrer em sítios gengivais saudáveis em idades precoces $^{1,21,22,24,31}$, sendo, portanto, um membro da microbiota fisiológica da placa dentária ${ }^{10,40}$.

\subsubsection{Avaliação da combinação de espécies bacterianas}

Embora espécies individuais de bactérias tenham sido identificadas como fatores de risco para destruição do tecido periodontal, muitas infecções em bolsas periodontais parecem ser infecções mistas. Certas combinações de espécies bacterianas têm sido implicadas na produção de potencial patogênico suficiente para causar a progressão da gengivite para a periodontite em humanos ${ }^{53,54}$. No estudo de TAKEUCHI et al. ${ }^{53}$, em 2001, T. denticola e $P$. gingivalis foram freqüentemente observadas em pacientes com periodontite crônica e agressiva, achados que corroboram os de outros estudos clínicos, os quais afirmam que a infecção por estas bactérias tem sido freqüentemente encontrada em bolsas periodontais profundas ${ }^{26,54}$. 
Em nosso estudo, nenhuma associação positiva entre combinações de bactérias foi encontrada nas duas avaliações (2003 e 2004), o que está de acordo com os resultados de KIMURA et al. ${ }^{21}$, em 2002, os quais também não encontraram associação positiva em crianças periodontalmente saudáveis.

Ademais, não houve correlação estatística, em ambas as avaliações, entre a condição de inflamação gengival (leve ou moderada) e a prevalência de cada uma destas espécies (ou da combinação de espécies) nas amostras de saliva, embora um grande número de amostras deva ser analisado para melhor se estabelecer esta correlação. Este resultado também foi obtido por WATANABE e FROMMEL ${ }^{59}$, em 1993, os quais, numa avaliação inicial em amostras de placa, observaram uma fraca correlação entre medidas de IG e a presença de $P$. gingivalis.

Vale ressaltar, entretanto, que apesar desta ausência de correlação estatística significativa entre parâmetros clínicos referentes à condição de saúde periodontal e a freqüência de potenciais microrganismos causadores de doença periodontal, um número bastante elevado de crianças apresentou pelo menos uma das quatro espécies bacterianas estudadas (81,3\% e 73,3\% nas avaliações de 2003 e 2004, respectivamente). Desta forma, é importante identificar os determinantes da colonização bucal destas bactérias periodontopatogênicas, uma vez que elas podem persistir na cavidade bucal de pacientes não tratados por períodos prolongados, aumentando o risco de desenvolverem doença periodontal no futuro. 


\section{Conclusões}

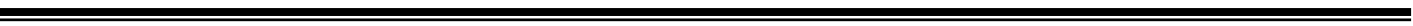




\section{CONCLUSÕES}

Com base no que foi exposto e discutido nos capítulos anteriores deste trabalho, pode-se concluir que:

- A utilização da técnica da PCR e de amostras de saliva parece ser bastante útil para se verificar a presença de patógenos periodontais na cavidade bucal de crianças em fase de dentadura mista.

- Apesar de a grande maioria das crianças avaliadas em 2003 e 2004 apresentar pelo menos uma bactéria periodontopatogênica na saliva, o parâmetro clínico de saúde periodontal (IG) mostrou apenas condições de inflamação gengival leve ou moderada em ambos os períodos avaliados.

- Uma vez que crianças infectadas por periodontopatógenos em idades precoces podem ser mais propícias ao desenvolvimento de periodontite quando chegarem à adolescência ou idade adulta, pode ser importante para a prevenção e o tratamento da doença, e não apenas para curiosidade científica, detectar microrganismos periodontopatogênicos no ambiente bucal de crianças o quanto antes possível. 
Anexos

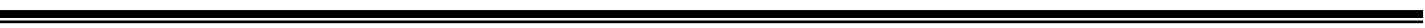


Anexo 1

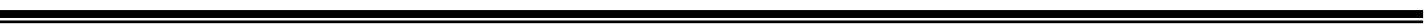




\section{Universidade de São Paulo Faculdade de Odontologia de Bauru}

Al. Dr. Octávio Pinheiro Brisolla, 9-75 - Bauru-SP - CEP 17012-901 - C.P. 73 PABX (0XX14)235-8000 - FAX (0XX14)223-4679

Comitê de Ética em Pesquiso

Processo $n^{\circ}$ 19/2003

Bauru, 27 de junho de 2003

Senhora Professora,

Informamos que após o envio das informações solicitadas, o projeto de pesquisa encaminhado a este Comitê denominado "Deteç̧āo de bactérias periodontopatogênicas na saliva de pacientes em fase de dentadura mista" de autoria de Vivien Thiemy Sakai, que será desenvolvido sob sua orientação e co-orientação do Prof. Dr. Carlos Ferreira dos Santos foi APROVADO, em reunião realizada no dia 25 de junho de 2003.

Comunicamos que após o envio do trabalho concluido, este Comitê enviará o parecer final, que será utilizado para a publicação do trabalho.

Atenciosamente,

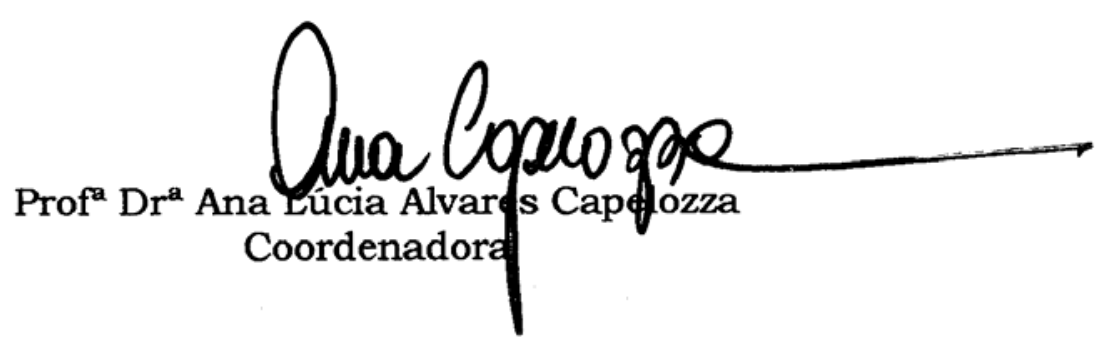

$\mathrm{Ilm}^{\mathrm{a}} \mathrm{Sr}^{\mathrm{a}} \mathrm{Prof}^{\mathrm{a}} \mathrm{Dr}^{\mathrm{a}}$ Maria Aparecida de Andrade Moreira Machado

DD. Docente do Departamento de Odontopediatria, Ortodontia e Saúde Coletiva 
Anexo 2

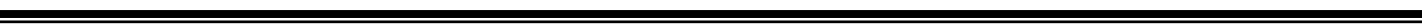




\section{Faculdade de Odontologia de Bauru}

Al. Dr. Octávio Pinheiro Brisolla, 9-75 - Bauru-SP - CEP 17012-901 -

C.P. 73

PABX (0XX14) 3235-8000 - FAX (0XX14) 3223-4679

\section{CARTA DE INFORMAÇÃO AO PACIENTE}

$1^{\mathrm{a}}$ via

As informações contidas nesta carta são referentes à pesquisa de título "Detecção de bactérias periodontopatogênicas na saliva de crianças em fase de dentadura mista", a qual será realizada pela aluna de mestrado Vivien Thiemy Sakai, sob a orientação da Profa. Dra. Maria Aparecida de Andrade Moreira Machado e co-orientação do Prof. Dr. Carlos Ferreira dos Santos.

A referida pesquisa tem como objetivos:

- Verificar na saliva das crianças a presença de algumas bactérias causadoras de doenças que acometem a gengiva.

- Correlacionar a presença dessas bactérias com a condição bucal da criança, observada por meio da presença de placa e de sangramento da gengiva.

O experimento constará das seguintes etapas: entrevista com os pais e/ou responsáveis, coleta de saliva da criança e exame odontológico (clínico e periodontal). A saliva coletada será levada ao laboratório para realização de exame que possam detectar a presença de bactérias.

Essa pesquisa fornecerá dados importantes com relação à presença de algumas bactérias causadoras de doenças que acometem a gengiva de crianças com idade entre 6 e 8 anos, cuja detecção precoce poderá ser um instrumento importante para a prevenção e tratamento dessas doenças.

Os pais e/ou responsáveis terão a garantia de receber esclarecimento de qualquer dúvida sobre os procedimentos, riscos, benefícios e outros assuntos relacionados com a pesquisa. Qualquer dúvida ou problema, por favor entrar em contato com um dos pesquisadores nos telefones 3235-8225 (Clínica de Odontopediatria) ou 3235-8218 (Departamento de Odontopediatria).

\section{TERMO DE CONSENTIMENTO LIVRE E ESCLARECIDO}

Pelo presente instrumento que atende às exigências legais, o Sr. (a) portador da cédula de identidade , após leitura minuciosa da CARTA DE INFORMAÇÃO AO PACIENTE, devidamente explicada pelos profissionais em seus mínimos detalhes, ciente dos serviços e procedimentos aos quais será submetido, não restando quaisquer dúvidas a respeito do lido e explicado, firma seu CONSENTIMENTO LIVRE E ESCLARECIDO concordando que a criança

participe da pesquisa proposta.

Fica claro que o paciente ou seu representante legal, pode a qualquer momento retirar seu CONSENTIMENTO LIVRE E ESCLARECIDO e deixar de participar desta pesquisa e ciente de que todas as informações prestadas tornaram-se confidenciais e guardadas por força de sigilo profissional (Art. $9^{\circ}$ do Código de Ética Odontológica).

Por estarem de acordo assinam o presente termo.

Bauru-SP, de de 
Anexo 3

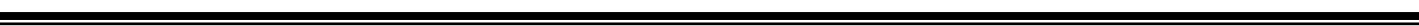


Faculdade de Odontologia de Bauru

Al. Dr. Octávio Pinheiro Brisolla, 9-75 - Bauru-SP - CEP 17012-901 C.P. 73

PABX (0XX14) 3235-8000 - FAX (0XX14) 3223-4679

\section{ANAMNESE}

Nome:

Idade:

Data de Nascimento:

Gênero: $\square \mathrm{M} \quad \square \mathrm{F}$

1. Está sob cuidados médicos?

2. Está tomando algum medicamento?

3. Tomou algum medicamento nos últimos 6 meses?

4. Sofreu alguma operação recentemente?

5. Sente dores nas articulações?

6. Tem febres freqüentes?

7. Qual foi a última vez que foi ao dentista?

8. Já sentiu a boca dolorida alguma vez?

9. Suas gengivas sangram quando escova os dentes?

10. Já fez algum tratamento para as gengivas alguma vez? 
Anexo 4 ב 


\section{UNIVERSIDADE DE SÃO PAULO \\ Faculdade de Odontologia de Bauru}

Al. Dr. Octávio Pinheiro Brisolla, 9-75 - Bauru-SP - CEP 17012-901 - C.P. 73 PABX (0XX14) 3235-8000 - FAX (0XX14) 3223-4679

Departamento de Odontopediatria, Ortodontia e Saúde Coletiva

Nome:

Gênero: $\square \mathrm{M} \quad \square \mathrm{F}$ Idade:

Data de Nascimento:

Examinadora:

ÍNDICE GENGIVAL (Löe e Silness)

\begin{tabular}{|c|c|c|c|c|c|c|c|}
\hline & \multicolumn{3}{|c|}{ MAXILA } & \multicolumn{3}{|c|}{ MANDÍBULA } & \\
\hline & $\mathbf{1 6}$ & $\mathbf{1 2 / 5 2}$ & $\mathbf{6 4}$ & $\mathbf{3 6}$ & $\mathbf{3 2 / 7 2}$ & $\mathbf{8 4}$ & Média \\
\hline Vestibular & & & & & & & \\
\hline Mesial & & & & & & & \\
\hline Lingual & & & & & & & \\
\hline Distal & & & & & & & \\
\hline Média & & & & & & & \\
\hline
\end{tabular}

\section{Critérios para o Índice Gengival}

0 = Ausência de inflamação (gengiva uniformemente rosada)

1 = Inflamação leve (pequena mudança de cor e textura gengivais, sem sangramento à palpação)

2 = Inflamação moderada (gengiva moderadamente avermelhada, vítrea, edemaciada e hipertrófica, com sangramento à palpação)

3 = Inflamação severa (gengiva nitidamente

avermelhada, hipertrófica, com tendência ao sangramento espontâneo e presença de ulceração)

Nome:

Gênero: $\square \mathrm{M} \quad \square \mathrm{F}$ Idade:___ Data de Nascimento:

Examinadora:

ÍNDICE GENGIVAL (Löe e Silness)

\begin{tabular}{|c|c|c|c|c|c|c|c|}
\hline & \multicolumn{3}{|c|}{ MAXILA } & \multicolumn{3}{|c|}{ MANDÍBULA } & \\
\hline & $\mathbf{1 6}$ & $\mathbf{1 2 / 5 2}$ & $\mathbf{6 4}$ & $\mathbf{3 6}$ & $\mathbf{3 2 / 7 2}$ & $\mathbf{8 4}$ & Média \\
\hline Vestibular & & & & & & & \\
\hline Mesial & & & & & & & \\
\hline Lingual & & & & & & & \\
\hline Distal & & & & & & & \\
\hline Média & & & & & & & \\
\hline
\end{tabular}

\section{Critérios para o Índice Gengival}

0 = Ausência de inflamação (gengiva uniformemente rosada)

1 = Inflamação leve (pequena mudança de cor e textura gengivais, sem sangramento à palpação)

2 = Inflamação moderada (gengiva moderadamente avermelhada, vítrea, edemaciada e hipertrófica, com sangramento à palpação)

3 = Inflamação severa (gengiva nitidamente

avermelhada, hipertrófica, com tendência ao sangramento espontâneo e presença de ulceração) 
Anexo 5

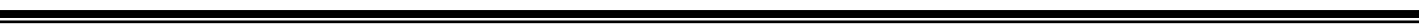


cebola

Data: Fri, 18 Jun 2004 14:06:04 +0300

De: Jaana Matto <Jaana.Matto@vtt.fi>

Para: Carlos Ferreira dos Santos <cebola@usp.br>

Assunto: Re: Information regarding one of your manuscripts

Dear Carlos Santos,

I apologize my very late response to your e-mail. Chelex is not water soluble and you should perform pipetting by adding a magnetic stirring to your bottle. I advise you also to test Instagene matrix system (Bio Rad) since it is a more advanced version of the practically same protocol as in our manuscript (it is however more expensive).

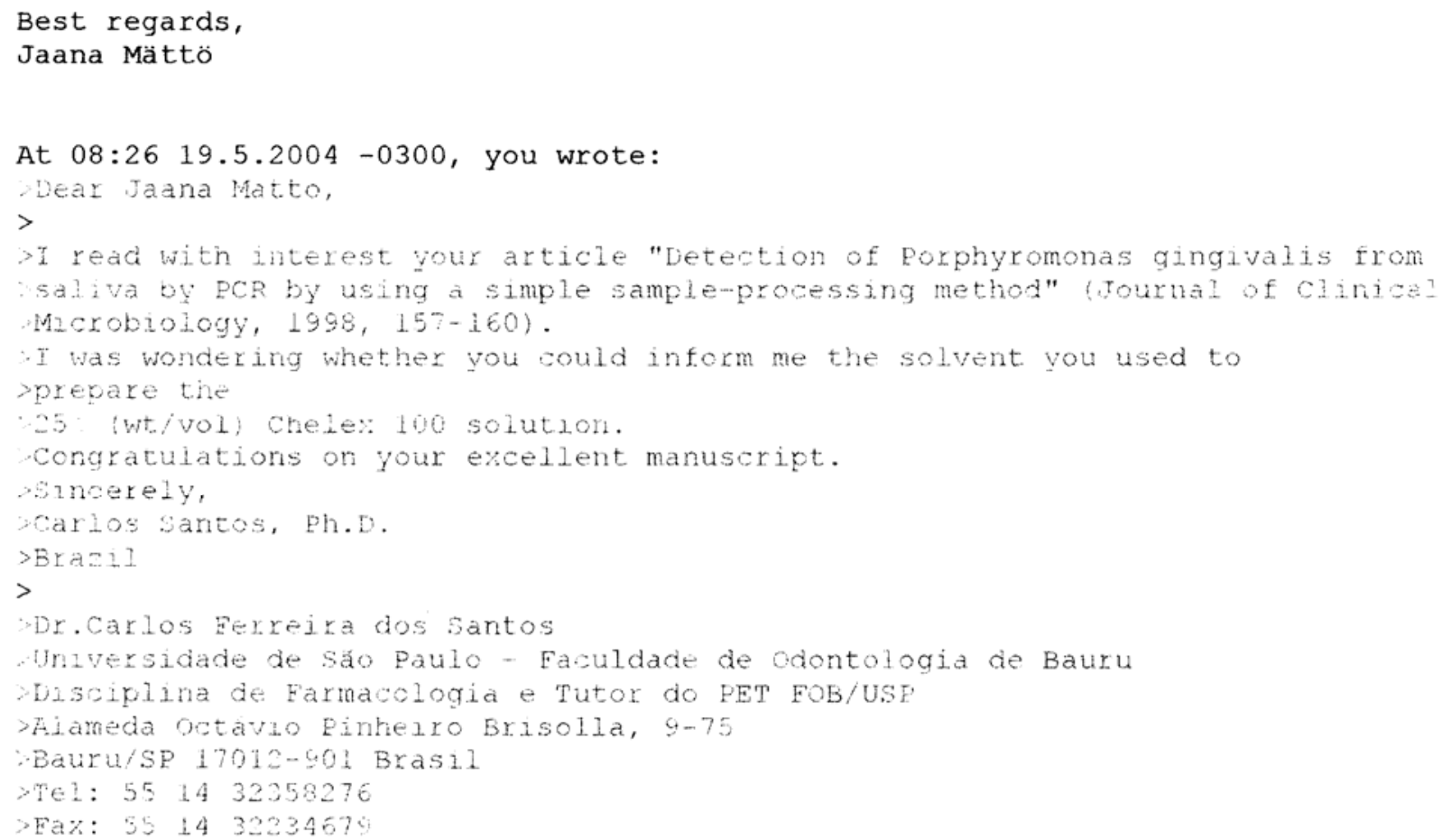




\section{Referências Bibliográficas}




\section{REFÊNCIAS BIBLIOGRÁFICAS}

1- ABRAHAM, J. et al. Assessing periodontal pathogens in children with varying levels of oral hygiene. J. Dent. Child., v.57, n.3, p.189-93, May/June 1990.

2- ALBANDAR, J.M.; TINOCO, E.M. Global epidemiology of periodontal diseases in children and young persons. Periodontol. 2000, v.29, n.1, p.153-76, Apr. 2002.

3- ALBANDAR, J.M.; RAMS, T.E. Risk factors for periodontitis in children and young persons. Periodontol. 2000, v.29, n.1, p.207-22, Apr. 2002.

4- ASHIMOTO, A. et al. Polymerase chain reaction detection of 8 putative periodontal pathogens in subgingival plaque of gingivitis and advanced periodontitis lesions. Oral Microbiol. Immunol., v.11, n.4, p.266-73, Aug. 1996.

5- ASIKAINEN, S. et al. Can one acquire periodontal bacteria and periodontitis from a family member? J. Am. Dent. Assoc., v.128, n.9, p.1263-71, Sept. 1997.

6- BARRON, S.L.; RIVIERE, G.R.; SIMONSON, L.G. Use of monoclonal antibodies to enumerate spirochetes and identify Treponema denticola in 
dental plaque of children, adolescents and young adults. Oral Microbiol. Immunol., v.6, n.2, p.97-101, Apr. 1991.

7- BEIKLER, T. et al. Microbiological shifts in intra- and extraoral habitats following mechanical periodontal therapy. J. Clin. Periodontol., v.31, n.9, p.777-83, Sept. 2004.

8- CHEN, C.; SLOTS, J. Microbiological tests for Actinobacillus actinomycetemcomitans and Porphyromonas gingivalis. Periodontol. 2000, v.20, p.53-64, June 1999.

9- CONRADS, G. et al. Simultaneous detection of Bacteroides forsythus and Prevotella intermedia by $16 \mathrm{~S}$ rRNA gene-directed multiplex PCR. J. Clin. Microbiol., v.37, n.5, p.1621-4, May 1999.

10-CONRADS, G. et al. PCR reaction and dot-blot hybridization to monitor the distribution of oral pathogens within plaque samples of periodontally healthy individuals. J. Periodontol., v.67, n.10, p.994-1003, Oct. 1996.

11-COSTA, B. et al. Clinical and microbiological evaluation of the periodontal status of children with unilateral complete cleft lip and palate. Cleft Palate Craniofac., v.40, n.6, p.585-9, Nov. 2003. 
12-DOUNGUDOMDACHA, S.; RAWLINSON, A.; DOUGLAS, C.W.I. Enumeration of Porphyromonas gingivalis, Prevotella intermedia and Actinobacillus actinomycetemcomitans in subgingival plaque samples by a quantitative-competitive PCR method. J. Med. Microbiol., v.49, n.10, p.861-74, Oct. 2000.

13-GAFAN, G.P. et al. Prevalence of periodontal pathogens in dental plaque of children. J. Clin. Microbiol., v.42, n.9, p.4141-6, Sept. 2004.

14-GREENSTEIN, G.; LAMSTER, I. Changing periodontal paradigms: therapeutic implications. Int. J. Periodontics Restorative Dent., v.20, n.4, p.336-57, Aug. 2000.

15-HAFFAJEE, A.D.; SOCRANSKY, S.S. Microbial etiological agents of destructive periodontal diseases. Periodontol. 2000, v.5, p.78-111, June 1994.

16-HAYASHI, F. et al. PCR detection of Capnocytophaga species in dental plaque samples from children aged 2 to 12 years. Microbiol. Immunol., v.45, n.1, p.17-22, 2001.

17-IRFAN, U.M.; DAWSON, D.V.; BISSADA, N.F. Assessment of familial patterns of microbial infection in periodontitis. J. Periodontol., v.70, n.11, p.1406-18, Nov. 1999. 
18-JENKINS, W.M.M.; PAPAPANOU, P.N. Epidemiology of periodontal disease in children and adolescents. Periodontol. 2000, v.26, n.6, p.1632, June 2001.

19-KAMMA, J.J. et al. Profile of subgingival microbiota in children with mixed dentition. Oral Microbiol. Immunol., v.15, n.2, p.103-11, Apr. 2000.

20-KAWADA, M. et al. Prevalence of Porphyromonas gingivalis in relation to periodontal status assessed by real-time PCR. Oral Microbiol. Immunol., v.19, n.5, p.289-92, Oct. 2000.

21-KIMURA, S. et al. Periodontopathic bacterial infection in childhood. J. Periodontol., v.73, n.1, p.20-6, Jan. 2002.

22-KISBY, L.E. et al. DNA probe detection of key periodontal pathogens in juveniles. J. Pedod., v. 13, n. 3, p.222-30, 1989.

23-KINANE, D.F. Periodontal disease in children and adolescents: introduction and classification. Periodontol. 2000, v.26, n.6, p.7-15, June 2001.

24-KÖNÖNEN, E.; ASIKAINEN, S.; JOUSIMIES-SOMER, H. The early colonization of Gram-negative anaerobic bacteria in edentulous infants. Oral Microbiol. Immunol., v.7, n.1, p.28-31, Feb. 1992. 
25-KUBONIWA, M. et al. Quantitative detection of periodontal pathogens using real-time polymerase chain reaction with TaqMan probes. Oral Microbiol. Immunol., v.19, n.3, p.168-76, June 2004.

26-LAMELL, C.W. et al. Acquisition and colonization stability of Actinobacillus actinomycetemcomitans and Porphyromonas gingivalis in children. J. Clin. Microbiol., v.38, n.3, p.1196-9, Mar. 2000.

27-LIÉBANA, J.; CASTILLO, A.M.; ÁlVAREZ, M. Periodontal diseases: microbiological considerations. Med. Oral Patol. Oral Cir. Bucal, v.9, p.82-91, 2004. Supplement.

28-LÖE, H.; SILNESS, J. Periodontal disease in pregnancy I: prevalence and severity. Acta Odontol. Scand., v.21, n.6, p.533-51, 1963.

29-MALHEIROS, V.J.; AVILA-CAMPOS, M.J. Detection of pathogens from periodontal lesions. Rev. Saude Publica, v.38, n.5, p.723-8, Oct. 2004.

30-MÄTTÖ, J. et al. Detection of Porphyromonas gingivalis from saliva by PCR by using a simple sample-processing method. J. Clin. Microbiol., v.36, n.1, p.157-60, Jan. 1998. 
31-MÄTTÖ, J. et al. Distribution and genetic analysis of oral Prevotella intermedia and Prevotella nigrescens. Oral Microbiol. Immunol., v.11, n.2, p.96-102, Apr. 1996.

32-MAYANAGI, G. et al. Detection frequency of periodontitis-associated bacteria by polymerase chain reaction in subgingival and supragingival plaque of periodontitis and healthy subjects. Oral Microbiol. Immunol., v.19, n.6, p.379-85, Dec. 2004.

33-MCCLELLAN, D.L.; GRIFFEN, A.L.; LEYS, E.J. Age and prevalence of Porphyromonas gingivalis in children. J. Clin. Microbiol., v.34, n.8, p.2017-9, Aug. 1996.

34-MEURMAN, J.H. et al. Identification of Bacteroides forsythus in subgingival dental plaque with the aid of a rapid PCR method. J. Dent. Res., v.76, n.7, p.1376-80, July 1997.

35-MODÉER, T.; WONDIMU, B. Periodontal diseases in children and adolescents. Dent. Clin. North. Am., v.44, n.3, p.633-58, July 2000.

36-MORINUSHI, T. et al. The relationship between gingivitis and colonization by Porphyromonas gingivalis and Actinobacillus actinomycetemcomitans in children. J. Periodontol., v.71, n.3, p.403-9, Mar. 2000. 
37-OKADA, $H$. et al. Diagnostic strategies of periodontitis based on the molecular mechanisms of periodontal tissue destruction. Oral Disease, v.2, n.1, p.87-95, Mar. 1996.

38-OKADA, M.; HAYASHI, F.; NAGASAKA, N. Detection of Actinobacillus actinomycetemcomitans and Porphyromonas gingivalis in dental plaque samples from children 2 to 12 years of age. J. Clin. Periodontol., v.27, n.10, p.763-8, Oct. 2000.

39-OKADA, M.; HAYASHI, F.; NAGASAKA, N. PCR detection of 5 putative periodontal pathogens in dental plaque samples from children 2 to 12 years of age. J. Clin. Periodontol., v.28, n.6, p.576-82, June 2001.

40-OOSHIMA, T. et al. Occurrence of periodontal bacteria in healthy children: a 2-year longitudinal study. Community Dent. Oral Epidemiol., v.31, n.6, p.417-25, Dec. 2003.

41-PEREA, E.J. Oral flora in the age of molecular biology. Med. Oral Patol. Oral Cir. Bucal, v.9, p.6-10, 2004. Supplement.

42-QUERIDO, S.M.R. et al. Avaliação clínica e microbiana da terapia periodontal mecânica em indivíduos com periodontite crônica. Cienc. Odontol. Bras., v.7, n.1, p.43-51, jan./mar. 2004. 
43-ROSA, O.P.S. et al. Periodontopathogens in the saliva and subgingival dental plaque of a group of mothers. Pesqui. Odontol. Bras., v.16, n.4, p.313-8, Oct./Dec. 2002.

44-SAKAMOTO, M. et al. Comparison of the oral bacterial flora in saliva from a healthy subject and two periodontitis patients by sequence analysis of 16S rDNA libraries. Microbiol. Immunol., v.44, n.8, p.643-52, 2000.

45-SAKAMOTO, M. et al. Rapid detection and quantification of five periodontopathic bacteria by real time PCR. Microbiol. Immunol., v.45, n.1, p.39-44, 2001.

46-SANTOS, C.F. et al. Reverse transcription and polymerase chain reaction: principles and applications in dentistry. J. Appl. Oral Sci., v.12, n.1, p.1-11, Jan./Mar. 2004.

47-SANZ, M. et al. Methods of detection of Actinobacillus actinomycetemcomitans, Porphyromonas gingivalis and Tannerella forsythensis in periodontal microbiology, with special emphasis on advanced molecular techniques: a review. J. Clin. Periodontol., v.31, n.12, p.1034-47, Dec. 2004. 
48-SHELBURN, C.E. et al. Quantitative reverse transcription polymerase chain reaction analysis of Porphyromonas gingivalis gene expression in vivo. J. Microbiol. Methods, v.49, n.2, p.147-56, Apr. 2002.

49-SIRINIAN, G. et al. Periodontopathic bacteria in young health subjects of different ethnic backgrounds in Los Angeles. J. Periodontol., v.73, n.3, p.283-8, Mar. 2002.

50-SLOTS, J. Actinobacillus actinomycetemcomitans and Porphyromonas gingivalis in periodontal disease: introduction. Periodontol. 2000, v.20, p.7-13, June 1999.

51-SLOTS, J. et al. Detection of putative periodontal pathogens in subgingival specimens by $16 \mathrm{~S}$ ribosomal DNA amplification with the polymerase chain reaction. Clin. Infect. Dis., v.20, p.S304-7, June 1995. Supplement 2.

52-SPENCER, J.A.; BEIGHTON, D.; HIGGINS, T.J. Periodontal disease in five- and six-year old children. J. Periodontol., v.54, n.1, p.19-22, Jan. 1983.

53-TAKEUCHI, Y. et al. Treponema socranskii, Treponema denticola, and Porphyromonas gingivalis are associated with severity of periodontal tissue destruction. J. Periodontol., v.72, n.10, p.1354-63, Oct. 2001. 
54-TANAKA, S. et al. Frequency of reactivity for Porphyromonas gingivalis and Prevotella spp. in supra- and subgingival plaques, and periodontal clinical parameters according to subject age. J. Periodontol., v.73, n.8, p.877-85, Aug. 2002.

55-UMEDA, M. et al. The distribution of periodontopathic bacteria among Japanese children and their parents. J. Periodont. Res., v.39, n.6, p.398404, Dec. 2004.

56-UMEDA, M. et al. The utility of whole saliva to detect the oral presence of periodontopathic bacteria. J. Periodontol., v.69, n.7, p.828-33, July 1998.

57-VON TROIL-LINDÉN, B. et al. Salivary levels of suspected periodontal pathogens in relation to periodontal status and treatment. J. Dent. Res., v. 74, n.11, p.1789-95, Nov. 1995.

58-WAHLFORS, J. et al. Simultaneous detection of Actinobacillus actinomycetemcomitans and Porphyromonas gingivalis by a rapid PCR method. J. Dent. Res., v.74, n.11, p.1796-801, Nov. 1995.

59-WATANABE, K.; FROMMEL, T.O. Detection of Porphyromonas gingivalis in oral plaque samples by use of the polymerase chain reaction. J. Dent. Res., v.72, n.6, p.1040-4, June 1993. 
60-WATANABE, K.; FROMMEL, T.O. Porphyromonas gingivalis, Actinobacillus actinomycetemcomitans and Treponema denticola detection in oral plaque samples using the polymerase chain reaction. $\mathbf{J}$. Clin. Periodontol., v.23, n.3, p.212-9, Mar. 1996.

61-YOSHIDA, A. et al. TaqMan real-time polymerase chain reaction assay for the correlation of Treponema denticola numbers with the severity of periodontal disease. Oral Microbiol. Immunol., v.19, n.3, p.196-200, June 2004. 
Abstract (20) 


\begin{abstract}
To evaluate the prevalence of 4 putative periodontopathic bacteria (Actinobacillus actinomycetemcomitans, Porphyromonas gingivalis, Prevotella nigrescens and Treponema denticola), by polymerase chain reaction (PCR) assay, in saliva of children with mixed dentition, and to correlate these findings with a clinical parameter of gingival health, the gingival index (GI). Besides, in order to verify the colonization stability of these bacteria, all the children were reassessed after a year. Sixty two $(96,9 \%)$ and $50(83,3 \%)$ children presented low gingival inflammation, whereas $2(3,1 \%)$ and $10(16,7 \%)$ had moderate scores in the assessments performed in 2003 and 2004, respectively. The majority of the patients (81,3\% in the first assessment and $73,3 \%$ in the second one) had detectable levels of at least one of the studied microorganisms. The prevalence found in this population was of $4,7 \%$ and $1,7 \%$ for $A$. actinomycetemcomitans, $6,3 \%$ and $8,3 \%$ for $P$. gingivalis, $23,4 \%$ and $48,3 \%$ for $P$. nigrescens, and $71,9 \%$ and 50\% for T. denticola in 2003 and 2004, respectively. No significant relationship between the $\mathrm{Gl}$ and the presence of these bacteria and the combination of different bacterial species was found. Despite the low values of $\mathrm{Gl}$, a high percentage of patients in this study harbored at least one putative periodontopathic bacteria in saliva in early age in both periods assessed. Therefore, preventive measures should be stressed to these patients in order to avoid the establishment and the development of periodontal disease in the future.
\end{abstract}

